OSEANOLOGI DAN LIMNOLOGI DI INDONESIA

Online ISSN: 2477-328X

Akreditasi RISTEKDIKTI No. 21/E/KPT/2018

http://jurnal-oldi.or.id

\title{
Kecenderungan Naiknya Suhu Permukaan Laut dan Resiliensi Karang Setelah Kejadian Pemutihan Karang 2010 dan 2016 di Taman Wisata Perairan (TWP) Pulau Pieh, Padang, Sumatra Barat
}

\author{
Sam Wouthuyzen ${ }^{1 *}$, Muhammad Abrar ${ }^{1}$, Corry Corvianawatie ${ }^{2,3}$, Suryo Kusumo ${ }^{4}$, Yogi Yanuar ${ }^{5}$, \\ Darmawan $^{5}$, Yennafri ${ }^{6}$, Abu Salatalohi ${ }^{2}$, Andriyatno Hanif ${ }^{5}$, Syeprianto Permana ${ }^{5}$, dan M. Y. Arafat ${ }^{6}$ \\ ${ }^{1}$ Loka Pengembangan Kompetensi Sumber daya Oseanografi (LPKSDMO) - LIPI, \\ ${ }^{2}$ Pusat Penelitian Oseanografi (P2O) LIPI, \\ ${ }^{3}$ University of Chinese Academy of Sciences, Beijing, China, \\ ${ }^{4}$ Institut Pertanian Bogor (IPB). \\ ${ }^{5}$ Loka Kawasan Konservasi Perairan Nasional (LKKN), Pekanbaru, \\ ${ }^{6}$ Yayasan Minang Bahari, Padang. \\ *Email: swouthuyzen@yahoo.com
}

Submitted 7 January 2019. Reviewed 11 April 2019. Accepted 27 January 2020.

DOI: 10.14203/oldi.2020.v5i1.236

\begin{abstract}
Abstrak
Kejadian pemutihan karang (coral bleaching) telah melanda hampir seluruh perairan Indonesia sedikitnya empat kali antara tahun 1982-2016. Dua kejadian terbaru (2010 dan 2016) telah dibahas mendalam, namun belum ada kajian rinci pada suatu lokasi yang spesifik, seperti di Taman Wisata Perairan (TWP) Pulau Pieh, perairan Padang, Sumatra Barat yang dipengaruhi oleh massa air Samudra Hindia. Tulisan ini bertujuan mengkaji kecenderungan naiknya suhu permukaan laut (SPL) pada kejadian pemutihan karang 2010 dan 2016 dan resiliensi karang setelah kejadian tersebut. Pada kajian ini data SPL jangka panjang hasil pemindaian citra satelit Aqua MODIS digunakan secara intensif. Hasil kajian menunjukkan bahwa SPL rata-rata bulanan tertinggi (MMM) yang dapat ditolerir oleh karang di TWP ini adalah $29,6^{\circ} \mathrm{C}$, lebih tinggi daripada seluruh perairan Indonesia $\left(29,1^{\circ} \mathrm{C}\right)$. Selisih antara SPL Anomali dan SPL normal (MMM) atau disebut Hot Spot (HS) rata-rata telah melampaui MMM pada kejadian pemutihan tahun 2010 sekitar $0,4-0,5^{\circ} \mathrm{C}$ dengan puncaknya di bulan April dan tingkat keparahan alert-1 (DHW < $8^{\circ} \mathrm{C}$-minggu; karang mengalami pemutihan sebagian). Tahun $2016 \mathrm{HS}$ rata-rata meningkat $0,5 \sim 1,0^{\circ} \mathrm{C}$ dengan puncak di bulan Jan-Feb dan Mei-Juni dan tingkat keparahan Alert-2 (DHW $\geq 8^{\circ} \mathrm{C}$-minggu, karang mengalami pemutihan berat, luas dan sebagian mati). Satu tahun sebelumnya (2015) terlihat juga HS rata-rata sebesar 0,3-0,8 ${ }^{\circ} \mathrm{C}$ dan $\mathrm{DHW} \sim 4^{\circ} \mathrm{C}$-minggu. Hal ini menunjukkan bahwa kejadian pemutihan karang di TWP Pulau Pieh berulang-ulang dan panjang. Kecenderungan peningkatan SPL di TWP ini adalah $0,23^{\circ} \mathrm{C} /$ dekade lebih rendah dari seluruh perairan Indonesia $\left(0,36^{\circ} \mathrm{C} /\right.$ dekade). Kecenderungan ini menunjukkan bahwa terumbu karang di perairan Indonesia, termasuk TWP Pulau Pieh memiliki resiliensi tinggi untuk memulihkan dirinya, karena kecenderungan peningkatan SPL $<1,0^{\circ} \mathrm{C} /$ dekade. Dari 11 faktor kunci resiliensi karang, faktor positif yang menunjang resiliensi karang adalah rendahnya polusi, nutrien, sedimentasi, dan rendahnya aktivitas manusia yang tidak ramah lingkungan, sedangkan yang paling negatif adalah meledaknya populasi hewan laut Bulu Seribu, Acanthaster planci, disamping penyakit karang.
\end{abstract}

Kata Kunci: Kejadian pemutihan karang, SPL, Resiliensi, Mitigasi, TWP Pulau Pieh 


\begin{abstract}
Trend of Sea Surface Temperature Increase and Coral Resilience After Bleaching Events of 2010 and 2016 in The Marine Tourism Park (TWP) of Pieh Island, Padang, West Sumatra. The coral bleaching event has hit almost all of Indonesia's waters at least 4 times (in the last 34 years), which the last two events (2010 and 2016) have been discussed rather deeply. However, detailed studies in a specific location, such as in Marine Tourism Park (TWP) of Pieh Island, Padang waters, West Sumatra Province that influenced by the water mass of Indian Ocean have not yet been studied. The aim of this paper is to examine the trend of sea surface temperatures (SST)'s increase in the TWP of Pieh Island in 2010 and 2016 coral bleaching, and the coral resilience after the events. In this study, the long-term SST data acquired from the Aqua MODIS satellite images were used intensively. Results show that the highest mean monthly SST called MMM that corals can be tolerated in the TWP of Pieh is $29.6{ }^{\circ} \mathrm{C}$, higher than in all Indonesian waters $\left(29.1^{\circ} \mathrm{C}\right)$. The differences between the anomaly SST and the normal SST (MMM) or called Hot Spot (HS) has exceeded the average MMM in the 2010 bleaching event around $0.4-0.5{ }^{\circ} \mathrm{C}$ with its peak in April, and with alert-1 severity (Degree Heating Weeks (DHW) $<8{ }^{\circ} \mathrm{C}$-weeks; which means that the coral has partial bleaching with patchy pattern).In 2016, the HS increased by an average of $0.5 \sim 1.0{ }^{\circ} \mathrm{C}$ with peaks in January-February and May-June and with the severity of Alert-2 (DHW $\geq 8{ }^{\circ} \mathrm{C}$-weeks, which means corals experienced severe bleaching, over wider areas, and some of corals are died). One year earlier (2015), higher HS with an average value of $0.3-0.8{ }^{\circ} \mathrm{C}$ and DHW $\sim 4{ }^{\circ} \mathrm{C}$-weeks were also observed. This indicates that coral bleaching events in the TWP of Pieh Island is repeated and occurs for long periods. The trend of increasing SST in this TWP is $0.23^{\circ} \mathrm{C} /$ decade, lower than in the all Indonesian waters $\left(0.36{ }^{\circ} \mathrm{C} / \mathrm{decade}\right)$. This trend shows that coral reefs in Indonesian waters including this TWP have a high resilience to recover themselves from bleaching, since the trend of increasing SST $<1.0{ }^{\circ} \mathrm{C} /$ decade of the 11 coral resilience key factors, positive factors that support high coral resilience are low pollution/nutrients, low sedimentation (high water transparency), and low unfriendly of human activities, while the most negative one is the explosion of crown-of-thorns starfish, Acanthaster planci population as well as coral disease.
\end{abstract}

Keywords: Coral bleaching events, SST trend, Resielience, Mitigation, TWP of Pieh

\section{Pendahuluan}

Ekosistem terumbu karang adalah salah satu ekosistem dengan produktivitas sangat tinggi di wilayah pesisir di samping lamun dan mangrove (Anonymous, 2001), sehingga bisa menghasilkan barang dan jasa lingkungan (goods \& environment services) (Mumby \& Edwards, 2002). Ekosistem terumbu karang ditinjau dari aspek sosial-ekonomi-budaya merupakan pusat kehidupan/kesejahteraan bagi masyarakat pesisir dan pulau-pulau kecil di wilayah tropis dengan kontribusinya terhadap perekonomian dunia sebesar US\$ 30 miliar, termasuk nilai dari sektor rekreasi, pariwisata bahari, perikanan, proteksi pantai, dan layanan keanekaragaman hayati (Eakin et al., 2006).

Walaupun ekosistem terumbu karang memiliki kontribusi sangat besar bagi kesejahteraan masyarakat di wilayah pesisir dan pulau-pulau kecil, namun ekosistem terumbu karang di dunia termasuk Indonesia mengalami degradasi terkait dengan berbagai gangguan baik yang berasal dari aktivitas manusia, seperti sedimentasi, pencemaran, penangkapan ikan yang tidak ramah lingkungan (penggunaan bahan peledak, racun), maupun dari alam berupa 2 pemangsaan oleh hewan Bulu seribu, Acanthaster planchi, penyakit, serta perubahan iklim /pemanasan global yang menyebabkan kejadian pemutihan karang (coral bleaching) (Eakin et al., 2006).

Fenomena pemutihan karang adalah kejadian dimana hewan karang (Polip) melepaskan simbionnya, yaitu algae mikroskopis bersel tunggal dari Genus Symbiodinium yang dikenal sebagai zooxanthela (zooxanthellae) yang hidup pada jaringan karang akibat kenaikan suhu laut $1-2^{\circ} \mathrm{C}$ selama $\geq 4$ minggu, sehingga karang yang berwarna-warni indah hanya tinggal kerangkanya saja yang berwarna putih (Brown, 1997; Douglas, 2003; Marshall \& Schuttenberg, 2006; Guest et al., 2010; Eakin et al., 2016).

Secara fisiologi, kejadian pemutihan karang akan menurunkan proses hidup karang dan dalam kurun waktu lama dapat menyebabkan derajat kematian karang meningkat (Berkelmans et al., 2004; Eakin et al., 2016; Oliver et al., 2018). Oleh karena itu, pemutihan karang, perlu dipetakan, dipantau, dievaluasi dan dikaji, dengan penekanan khusus terhadap parameter/variable penyebabnya, yaitu suhu laut dengan menggunakan cara yang efektif dan efisien melalui teknik penginderaan jauh (remote sensing). 
Belakangan ini data satelit memiliki kapasitas yang dapat memberikan pemahaman yang lebih jelas tentang ancaman pemanasan global, yaitu penaikan suhu laut terhadap kejadian pemutihan karang dalam waktu yang hampir bersamaan (near-real time), secara spasial (global) melalui pengamatan yang berulang (repetitive) dan dalam jangka waktu pengamatan yang panjang (time series) (Eakin et al., 2010).

Kejadian pemutihan karang di perairan tropis dan sub-tropis dipicu secara episodik oleh fenomena El Nino (Goreau \& Hayes, 1994; Baker et al., 2008; Miranda et al., 2013; Ibrahin et al., 2017; Ompou, 2017), yang menaikkan suhu laut $1-2^{\circ} \mathrm{C}$ dan berpotensi mematikan karang dalam skala global (Gulberg, 1999; Donner et al., 2005; INCOIS 2011; Guest et al., 2012; Zhang, 2013). Kejadian ini di perairan Indonesia telah berlangsung empat kali, yaitu tahun 1982/1983, 1996/1997, 2010 dan 2015/2016. Dua kejadian terakhir telah dipantau dan dikaji oleh Wouthuyzen et al. (2015; 2018) menggunakan teknik penginderaan jauh, yaitu melalui analisa data suhu permukaan laut (SPL) jangka panjang (2002-2018) yang dihasilkan oleh citra satelit Aqua-MODIS. Meskipun demikian, kajian tersebut mencakup wilayah perairan Indonesia yang sangat luas $\left(91-142^{\circ} \mathrm{LS} ; 12^{\circ} \mathrm{LS}-8^{\circ} \mathrm{LU}\right)$ yang meliputi sedikitnya 15 provinsi dengan 20 wilayah kejadian pemutihan karang, termasuk empat negara tetangga (Singapura, Malaysia, Brunei, dan Timor Leste). Secara lokal, hampir sebagian besar wilayah kejadian pemutihan karang ini belum terkaji dan terungkap secara rinci seperti di Taman Wisata Perairan (TWP) Pulau Pieh, Sumatra Barat. Oleh karena itu, tujuan tulisan ini adalah mengkaji pengaruh perubahan iklim global berupa kecenderungan (trend) meningkatnya SPL terhadap fenomena pemutihan karang di TWP Pulau Pieh, berikut reseliensinya (daya lenting).

\section{Metodologi}

\section{Lokasi dan Waktu Kajian}

Lokasi kajian ini merupakan Kawasan Konservasi Perairan Nasional (KKPN) dengan fungsi sebagai Taman Wisata Perairan (TWP) Pulau Pieh dan Laut di sekitarnya, Provinsi Sumatera Barat tepatnya di sebelah barat wilayah administratif Kota Padang, Kota Pariaman, dan Kabupaten Padang Pariaman. Taman Wisata Perairan Pulau Pieh ditetapkan berdasarkan Keputusan Menteri Kelautan dan Perikanan Nomor KEP. 70/MEN/2009 tanggal 3 September 2009. Kawasan ini terdiri dari beberapa gugusan pulau-pulau kecil, yakni Pulau Bando, Pulau Pieh, Pulau Toran, Pulau Pandan, dan Pulau Air; termasuk beberapa gosong karang dengan luas kawasan keseluruhan mencapai 39.900 Ha. Selain TWP Pulau Pieh, kajian dilakukan pula di bagian utara gugusan pulau-pulau kecil lainnya, yakni di Pulau Kasiak, Pulau Angso Duo, Pulau Tangah dan Pulau Ujung yang masuk dalam Kawasan Konservasi Perairan Daerah (KKPD) Kota Pariaman; serta di bagian selatan TWP, yakni Pulau-pulau Sibuntar, Bindalang dan Sinyaru yang berada di bagian selatan, namun tidak termasuk dalam kawasan pengolahan (Gambar 1).

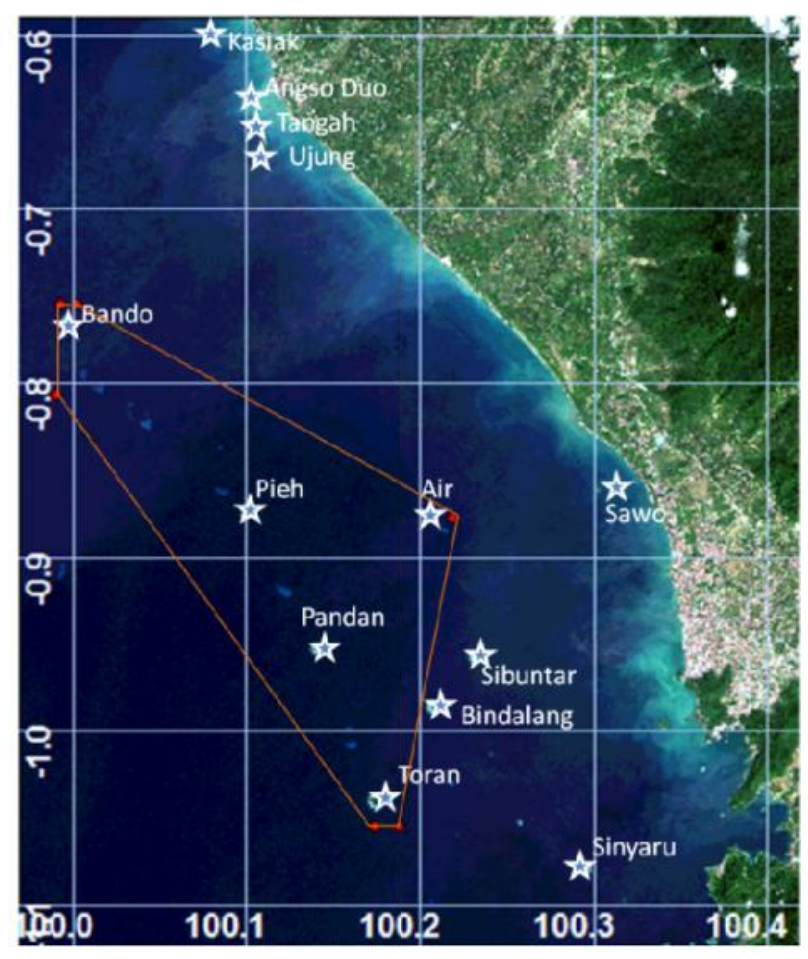

Gambar 1. Peta lokasi kajian TWP Pulau Pieh yang dibatasi garis merah.

Figure 1. Map of TWP Pieh Island (bordered by red line).

Pada kajian ini, pengumpulan data lapangan dilakukan pada bulan Juni-Juli 2018 untuk mengamati kondisi terumbu karang (biodiversitas karang dan tutupannya; biodiversitas ikan karang berikut kelimpahannya; pemangsaan karang oleh predator dan penyakit), serta berbagai parameter lingkungan yang mendukung kehidupan karang, seperti suhu laut, salinitas, transparansi perairan, oksigen terlarut, $\mathrm{pH}$, kandungan nutrien, dan sedimentasi.

\section{Sumber Data}

Dalam kajian ini, suhu permukaan laut (SPL) hasil pemindaian gelombang infra merah jauh (Thermal infrared/TIR) dari radiometer atau sensor MODIS (Moderate Resolution Imaging Spectroradiometer) pada satelit Aqua dengan panjang gelombang $11 \mu \mathrm{m}$ dan resolusi spasial $4 \mathrm{x}$ $4 \mathrm{~km}$ digunakan secara intensif. Data SPL 
Wouthuyzen et al.

tersebut diperoleh dari salah satu situs NASA, Amerika, yaitu situs Giovanni (Geospatial Interactive Online Visualization and analysis Infra-structure). Data SPL yang dipakai merupakan data SPL malam hari, dengan tujuan agar pengaruh silau matahari (sun glare) dapat ditiadakan dan variabilitas suhu akibat pemanasan di siang hari berkurang (INCOIS, 2011). Data yang dipakai adalah data SPL multi-temporal jangka panjang dari tahun 2003-2017 (15 tahun) yang mencakup: 1). Seluruh perairan Indonesia dan sekitarnya pada koordinat $92^{\circ}-142^{\circ}$ Bujur Timur (BT) dan $8,0^{\circ}$ Lintang Utara (LU) - 12, $0^{\circ}$ Lintang Selatan (LS), dan 2). Perairan TWP Pulau Pieh (99,95-104.50 ${ }^{\circ} \mathrm{BT}$, dan 1,05-5,95 $\left.{ }^{\circ} \mathrm{LS}\right)$.

\section{Data Analisis}

Prosedur penghitungan stres karang yang menyebabkan kejadian pemutihan karang dalam kajian ini mengikuti prosedur baku NOAA coral reef watch (http://coralreefwatch. noaa.gov diunduh 30 Agustus 2015) dan Indian National Centre for Ocean Information Services, INCOIS (2011) (Gambar 2). Pemutihan karang terjadi karena adanya peningkatan SPL yang tinggi (SPL anomali) di atas SPL maksimum dalam jangka waktu panjang (SPL normal). Oleh karena itu, langkah pertama adalah mendefinisikan terlebih dahulu SPL normal jangka panjang (minimal SPL 7 tahun berturut-turut) untuk Perairan Indonesia dan Perairan TWP Pieh. SPL normal adalah nilai SPL rata-rata bulanan yang tertinggi (Maximum Mean Monthly SST; MMM).

Kejadian pemutihan karang dilaporkan berlangsung dari bulan Januari- Februari hingga Juni 2010 dan pada bulan Maret-Juni 2016 (Wouthuyzen et al., 2015 ; 2018). Nilai SPL pada bulan-bulan tersebut (SPL Anomali) lebih tinggi daripada nilai SPL normal atau MMM. Selisih antara SPL anomali terhadap SPL Normal (MMM) disebut sebagai Hot Spot (HS) yang selanjutnya dipakai untuk menunjukkan kejadian pemutihan karang, jika HS $\geq 1{ }^{\circ} \mathrm{C}$. Jadi, HS bisa dinyatakan dalam persamaan:

\section{HS = SPL anomali bulan ke-i tahun $\mathbf{j}-$ SPL MMM bulan ke i tahun $\mathbf{j}$..... 1)}

$\mathrm{i}$ = Januari - Juni; dan j tahun 2010 atau 2016,

Pada tahap ini hanya HS bernilai positif saja yang dipakai dalam perhitungan selanjutnya, sedangkan HS $\leq 0^{\circ} \mathrm{C}$ menunjukkan tidak ada kejadian pemutihan karang (karang dalam keadaan baik). Jika HS berkisar $0-1{ }^{\circ} \mathrm{C}$, maka ini menunjukkan kondisi hati-hati, dan $\mathrm{HS} \geq 1{ }^{\circ} \mathrm{C}$ menunjukkan kondisi siaga.

Jika HS $\geq 1{ }^{\circ} \mathrm{C}$, maka langkah selanjutnya adalah mengetahui tingkat keparahan karang yang terkena dampak perubahan SPL, yaitu dengan jalan menghitung berapa minggu suhu anomali mendiami suatu perairan atau disebut dengan Degree Heating Weeks (DHW; ${ }^{\circ} \mathrm{C}-$ minggu) melalui persamaan berikut:
DHW j = ( HSi1 + HSi2 + HSi3 + .... HSin $) \times 4$ ................2)

$\mathrm{j}=$ Tahun (2010 atau 2016); HSin = HS bulan ke $\mathrm{i}$ Angka 4 diperoleh dari 1 bulan $=4$ minggu. DHW $\leq 4$ menandakan karang mengalami akumulasi stres karena suhu laut naik $1^{\circ} \mathrm{C}$ selama 4 minggu. DHW berkisar 4-8 menandakan karang mengalami pemutihan yang cukup nyata, sehingga menyebabkan kejadian pemutihan karang dengan sebaran yang tidak merata dan tidak begitu luas (sebagian-sebagian). DHW > 8 karang mengalami pemutihan dengan sebaran yang merata dan luas dan dapat mematikan karang. Nilai DHW atau disebut juga sebagai indeks pemutihan karang (Liu et al., 2003) dan digunakan untuk mengungkapkan tingkat keparahan dari kejadian tersebut di seluruh perairan Indonesia (Gambar 2). Kecendrungan peningkatan suhu beberapa tahun ke depan dapat diperoleh dengan memplotkan SPL rata-rata tahunan dari tahun 2003 hingga 2017 terhadap tahun (2003-2017) dimana SPL tersebut diukur oleh sensor MODIS dari citra satelit Aqua.

Untuk memperoleh gambaran tentang resiliensi karang di lokasi penelitian, digunakan beberapa acuan seperti Donner et al. (2005), McClanahan et al. (2012) dan Corvianawatie et al. (2018). 


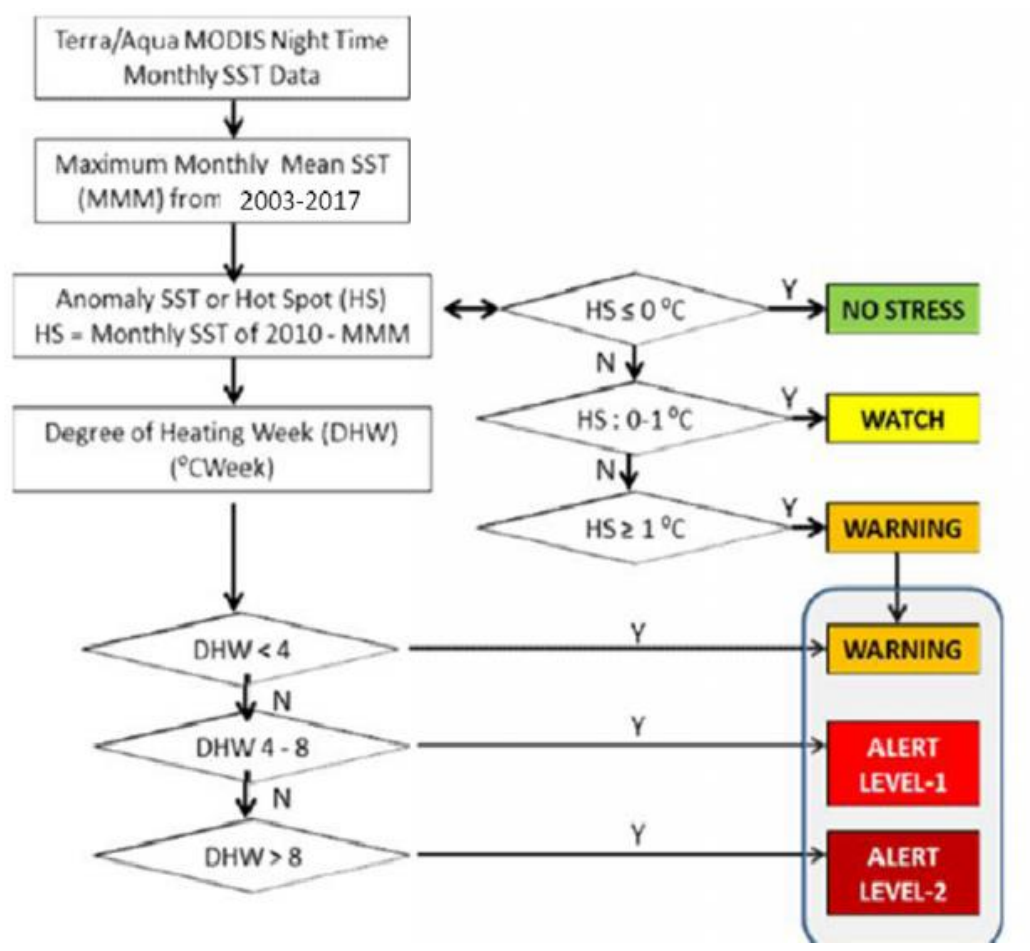
No thermal stress on
corals,

Low thermal Stress on corals

Thermal stress accumulate on corals

Strong thermal stress, Partial bleaching

Severe thermal stress wide spread bleaching With likelv mortalitv

Gambar 2. Metodologi dan kriteria penetapan status pemutihan karang (INCOIS, 2011).

Figure 2.Methodology and criteria for coral bleaching status (INCOIS, 2011).

\section{Hasil}

\section{Perairan Indonesia}

Sebelum membahas kejadian pemutihan karang dan kecenderungan naiknya SPL di TWP Pulau Pieh dan sekitarnya, maka terlebih dahulu perlu dilakukan tinjauan singkat kejadian pemutihan karang dan kecenderungan naiknya SPL untuk seluruh perairan Indonesia yang digunakan sebagai pembanding. Tinjauan singkat ini diringkas dari kajian Wouthuyzen et al. (2015; 2018). Data SPL jangka panjang seluruh perairan Indonesia $\left(91-142^{\circ} \mathrm{BT}, 8^{\circ} \mathrm{LU}-12^{\circ} \mathrm{LS}\right)$ (Tabel 1) dipakai untuk menghitung nilai MMM perairan Indonesia dengan nilai $29,1^{\circ} \mathrm{C}$. Pola perbedaan SPL pada kondisi normal (2002-2017) dan kejadiaan pemutihan karang tahun 2010 dan 2016 disajikan pada Gambar 3. Tabel 1 dan Gambar 3 menunjukkan bahwa ada peningkatan SPL ratarata (Hot Spot/HS) pada tahun 2010 dan 2016 di atas MMM jangka panjang sekitar $0,4-1,0^{\circ} \mathrm{C}$ pada bulan April-Juni selama 3 bulan. Dari gambar ini terlihat juga bahwa SPL tahun 2016 memiliki kekuatan lebih besar dalam membangkitkan kejadian pemutihan karang daripada tahun 2010. Hal tersebut terlihat pula pada Gambar 4, dimana sebaran DHW $>8^{\circ} \mathrm{C}$-minggu lebih luas, sehingga banyak terumbu karang mengalami pemutihan (Gambar 5) dan ada sebagian karang yang mati. Sedikitnya pada tahun 2016 ada 12 provinsi yang terkena dampak anomali suhu tinggi, khususnya perairan Indonesia bagian barat dan tengah, termasuk negara tetangga (Singapura, Malaysia, Brunei dan Timor Leste) (Wouthuyzen et al., 2018). Plot nilai SPL rata-rata tahunan terhadap tahun dimana SPL tersebut diukur (Tabel 1), memperlihatkan adanya kecenderungan penaikan SPL di perairan Indonesia dengan nilai $0,036{ }^{\circ} \mathrm{C}$ per tahun atau $0,36^{\circ} \mathrm{C}$ per dekade (Gambar 6). 
Wouthuyzen et al.

Tabel 1. Dinamika SPL malam hari dari citra satelit Aqua-MODIS di seluruh perairan Indonesia.

Table 1. The night time SST dynamics of Indonesian waters ackquired from AQUA-MODIS Satellite.

\begin{tabular}{|c|c|c|c|c|c|c|c|c|c|c|c|c|c|}
\hline YEAR & Jan & Feb & Mar & Apr & Mei & Jun & Jul & Agu & Sep & Okt & Nov & Des & $\begin{array}{l}\text { Yearly } \\
\text { Mean }\end{array}$ \\
\hline 2003 & 28.2 & 28.1 & 28.7 & 29.2 & 29.2 & 28.2 & 28.0 & 27.7 & 27.8 & 28.2 & 28.6 & 28.2 & 28.3 \\
\hline 2004 & 28.3 & 28.1 & 28.8 & 29.2 & 29.2 & 28.6 & 27.8 & 27.5 & 27.4 & 28.0 & 28.5 & 28.4 & 28.3 \\
\hline 2005 & 28.3 & 28.7 & 29.0 & 29.0 & 28.8 & 28.7 & 28.4 & 28.0 & 28.1 & 28.3 & 28.5 & 28.3 & 28.5 \\
\hline 2006 & 28.0 & 28.4 & 28.9 & 28.9 & 28.5 & 28.5 & 28.0 & 27.5 & 27.3 & 27.5 & 28.2 & 28.5 & 28.2 \\
\hline 2007 & 28.2 & 28.5 & 28.6 & 28.9 & 29.1 & 28.7 & 28.0 & 27.7 & 27.7 & 28.0 & 28.4 & 28.5 & 28.4 \\
\hline 2008 & 28.3 & 27.3 & 28.4 & 28.8 & 28.6 & 28.0 & 28.9 & 27.7 & 28.0 & 28.4 & 28.6 & 28.3 & 28.3 \\
\hline 2009 & 28.0 & 27.8 & 29.0 & 29.4 & 29.2 & 29.0 & 28.5 & 28.0 & 28.3 & 28.3 & 28.7 & 28.7 & 28.6 \\
\hline 2010 & 28.1 & 28.8 & 29.3 & 29.6 & 29.5 & 29.3 & 28.8 & 28.7 & 28.7 & 28.9 & 28.8 & 28.6 & 28.9 \\
\hline 2011 & 28.1 & 28.1 & 28.3 & 28.8 & 28.9 & 28.4 & 28.0 & 27.1 & 27.4 & 28.1 & 28.1 & 28.7 & 28.2 \\
\hline 2012 & 28.5 & 28.5 & 28.5 & 28.9 & 28.5 & 29.2 & 28.0 & 27.6 & 27.0 & 28.2 & 28.7 & 28.8 & 28.4 \\
\hline 2013 & 28.2 & 28.7 & 29.1 & 29.4 & 29.4 & 29.1 & 28.0 & 28.0 & 27.9 & 28.3 & 28.6 & 28.7 & 28.6 \\
\hline 2014 & 28.2 & 28.1 & 28.6 & 29.2 & 29.4 & 29.0 & 28.3 & 27.9 & 28.2 & 28.1 & 28.6 & 28.6 & 28.5 \\
\hline 2015 & 28.3 & 28.4 & 28.7 & 29.1 & 29.1 & 29.0 & 28.6 & 27.2 & 27.8 & 27.9 & 28.6 & 28.9 & 28.5 \\
\hline 2016 & 29.0 & 28.9 & 29.3 & 29.6 & 29.9 & 29.6 & 28.6 & 28.6 & 28.7 & 28.7 & 28.9 & 28.8 & 29.1 \\
\hline 2017 & 28.3 & 28.5 & 28.7 & 29.2 & . & 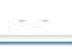 & $\cdots$ & - & $\cdots$ & & & & 28.7 \\
\hline $\begin{array}{l}\text { Monthly } \\
\text { Mean }\end{array}$ & 28.3 & 28.3 & 28.8 & 29.1 & 29.1 & 28.8 & 28.3 & 27.8 & 27.9 & 28.2 & 28.6 & 28.6 & $\cdots$ \\
\hline
\end{tabular}

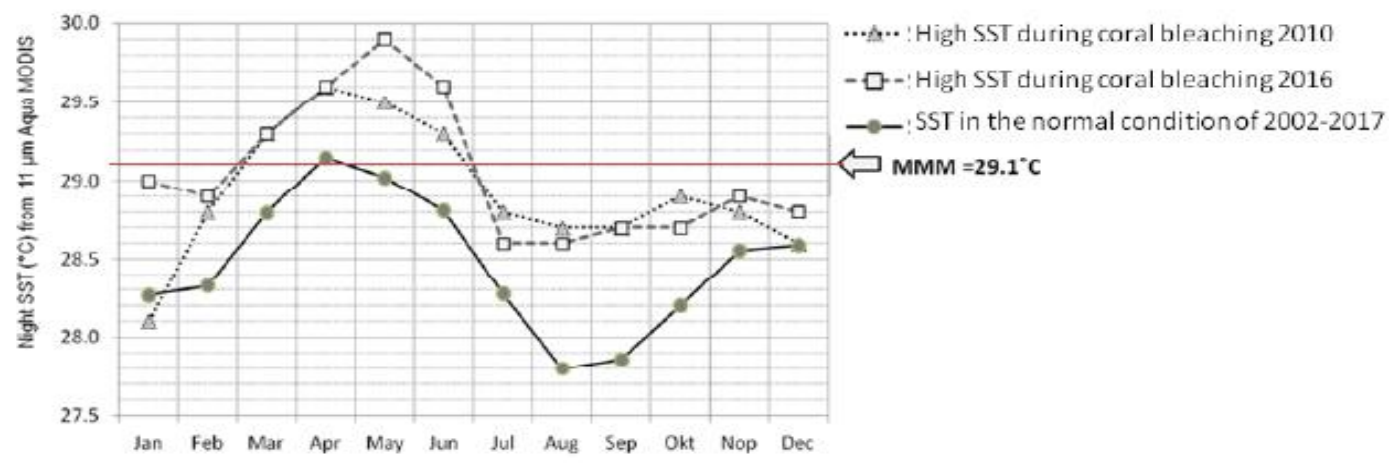

Gambar 3. Pola perbedaan SPL untuk seluruh perairan Indonesia pada kondisi normal (2002 - 2017) dengan nilai MMM 29, $1^{\circ} \mathrm{C}$ dan saat kejadiaan pemutihan karang tahun 2010 dan 2016.

Figure 3. The SST patern of Indonesian waters at normal condition (2002-2017) with MMM of $29.1{ }^{\circ} \mathrm{C}$, and during the coral bleaching events of 2010 and 2016.

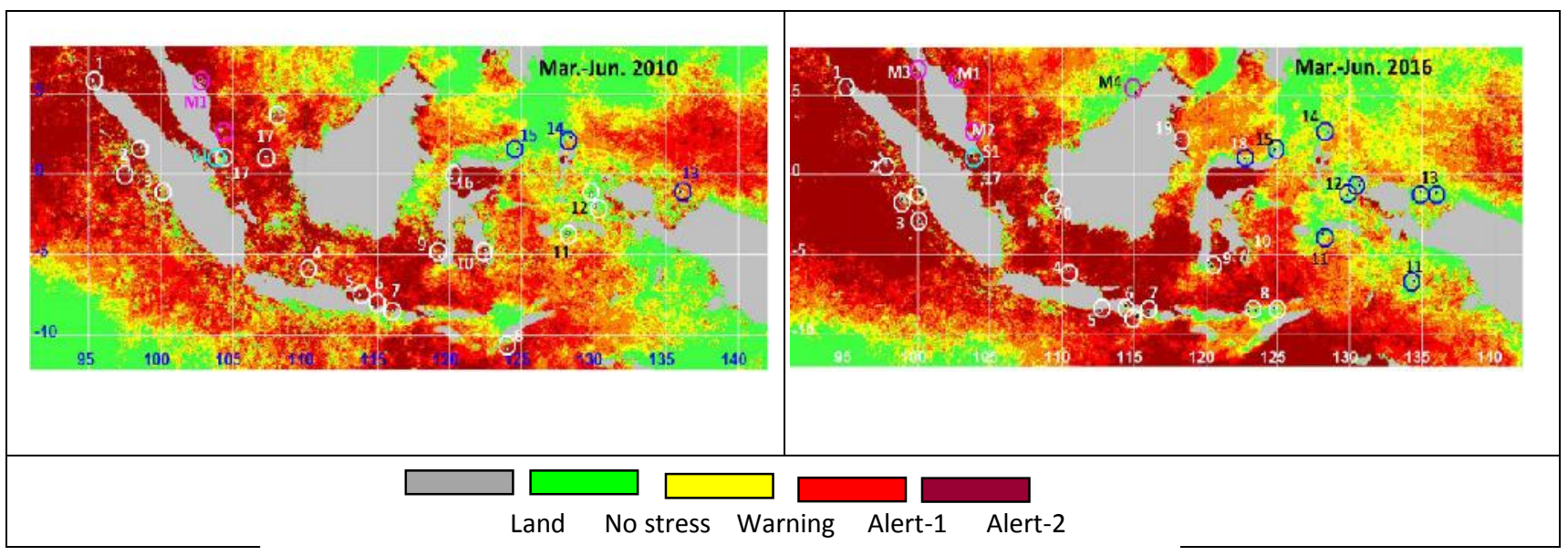

Gambar 4. Peta sebaran DHW yang menunjukkan kejadian pemutihan karang parah (Alert-1 dan -2) di perairan Indonesia pada tahun 2010 (Kiri) dan 2016 (Kanan) (Wouthuyzen et al., 2018).

Figure 4. The distribution map of DHW which indicated the severity of coral bleaching events (Alert-1 and 2) in Indonesian waters of 2010 (left) and 2016 (right) (Wouthuyzen et al., 2018). 


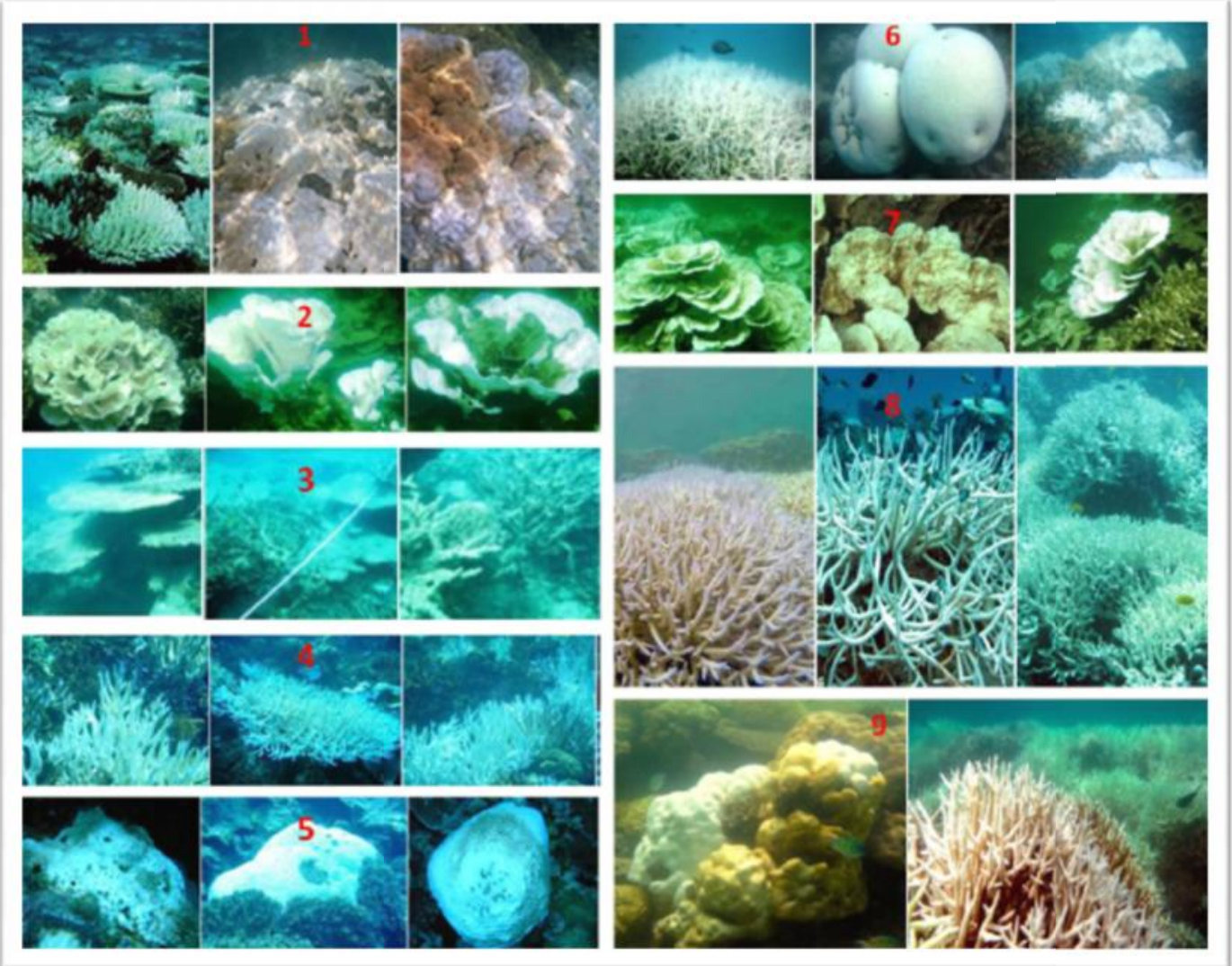

Gambar 5. Kejadian pemutihan karang di berbagai perairan Indonesia pada tahun 2010 (1. Aceh; 2. Sibolga; 3. Natuna; 4. Pangkep; dan 5. Wakatobi), dan tahun 2016 (6. Mentawai; 7. Tapanuli Tengah; 8. Pulau Merak, Sumatra Barat; dan 9. Sekotong, Lombok, 2016).

Figure 5. Coral bleaching events in various Indonesia Waters in 2010 (1. Aceh; 2. Sibolga; 3. Natuna 2010; 4. Pangkep; and 5. Wakatobi) and in 2016 (6. Mentawai; 7. Tapanuli Tengah; 8. Pulau Merak, Sumatra Barat and 9. Sekotong, Lombok).

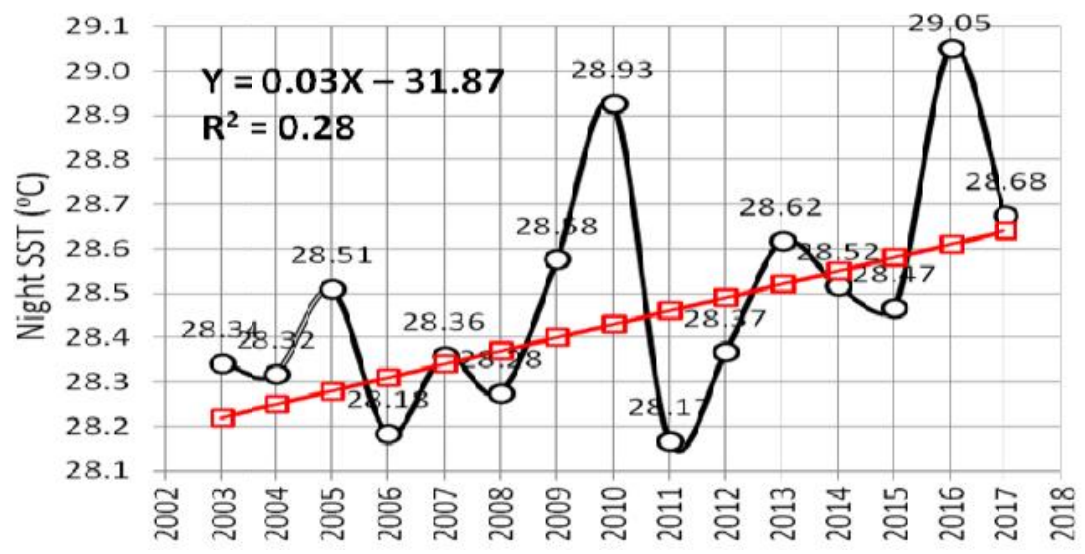

Gambar 6. Pola kecenderungan naiknya SPL di perairan Indonesia pada tahun 2003-2017.

Figure 6. Trend patern in SST increase in the Indonesian waters of 2003-2017.

\section{TWP Pulau Pieh dan sekitarnya}

Pada skala lokal, pola sebaran SPL atau DHW di perairan Indonesia sangat bervariasi dari suatu perairan ke perairan lainnya. Oleh karena itu, kami mengamati kejadian pemutihan karang di Taman Wisata Perairan (TWP) Pulau Pieh, Perairan Padang, Sumatra barat yang sejalan dengan kegiatan penelitian DDRG COREMAP CTI - LIPI. Lokasi ini sedikitnya telah dua kali terpapar kejadian pemutihan karang, yaitu pada tahun 2010 dan 2016 (Wouthuyzen et al., 2018). Oleh karena itu, kami memantau kecenderungan kenaikan SPL di TWP Pulau Pieh menggunakan data jangka panjang SPL dari citra satelit Aqua- 
Wouthuyzen et al.

MODIS yang sama. Tabel 2 memperlihatkan bahwa MMM untuk perairan ini cenderung lebih tinggi $\left(29,7^{\circ} \mathrm{C}\right)$ dibandingkan MMM untuk seluruh perairan Indonesia $\left(29,1^{\circ} \mathrm{C}\right)$. MMM adalah SPL dimana karang masih dapat beradaptasi terhadap suhu lingkungannya, atau karang tidak terganggu secara fisiologi.

Dari data SPL Tabel 2, terlihat bahwa Hot Spot (HS) terjadi pada bulan April-Mei 2010 dengan suhu $>0,4-0,5{ }^{\circ} \mathrm{C}$, sedangkan pada tahun 2016 HS terlihat pada bulan Mei-Juni 2016 sebesar $0,5-0,6{ }^{\circ} \mathrm{C}$, namun sebenarnya HS tertinggi $\left( \pm 1,0{ }^{\circ} \mathrm{C}\right)$ terlihat pada bulan Januari 2016. Pada tahun 2015 juga terlihat HS relatif tinggi pada bulan Mei-Juni. Hal ini menunjukkan bahwa kejadian pemutihan karang di TWP Pulau Pieh berlangsung berulang-ulang dan lama (hampir dua tahun). Gambar 7 memperlihatkan peta sebaran DHW Di TWP Pulau Pieh pada saat kejadian pemutihan karang bulan April-Mei 2010 (Alert-1), dan mencapai tingkat keparahan Allert-2 pada bulan Januari 2016 di Pulau Bando, namun pada umumnya seluruh TWP Pulau Pieh mengalami pemutihan karang dengan tingkat keparahan Allert-1.Pada Gambar 8 ditampilkan foto kondisi karang yang mengalami pemutihan, dimana terlihat jelas bahwa suhu laut pada saat itu bahkan mencapai $31^{\circ} \mathrm{C}\left(>1,4^{\circ} \mathrm{C}\right.$ di atas MMM atau $\mathrm{HS}=1,4^{\circ} \mathrm{C}$ ), dan mencapai kedalaman hingga 17 meter. Kegiatan transplantasi karang juga mengalami dampak pemutihan. Pada saat survei lapangan dilakukan (Juni-Juli 2018) SPL berkisar $29,1-30,0^{\circ} \mathrm{C}$ dengan nilai rata-rata $29,5^{\circ} \mathrm{C}$ (Tabel 3), sedangkan hasil pengukuran data citra satelit Aqua-MODIS berkisar antara 28,3-30,3 ${ }^{\circ} \mathrm{C}$ dengan nilai rata-rata $29,2{ }^{\circ} \mathrm{C}$ (Gambar 9). Nilai rata-sata SPL baik hasil pengukuran lapangan dan citra Aqua-MODIS lebih kecil dari nilai MMM TWP Pulau Pieh $\left(29,7^{\circ} \mathrm{C}\right)$, sehingga berdasarkan persamaan 1, Nilai HS berada pada kisaran -1,3 $<1{ }^{\circ} \mathrm{C}$. Kondisi tersebut menunjukkan bahwa tingkat keparahan pemutihan karang berada pada level DHW $\leq 0{ }^{\circ} \mathrm{C}$-minggu hingga $<4^{\circ} \mathrm{C}$-minggu. Hal ini berarti karang terbebas dari tekanan suhu (no stress on coral).

Plot SPL rata-rata tahunan terhadap waktu (tahun) ketika SPL diukur dari data pada Tabel 2 menunjukkan pola yang bervariasi (Gambar 10), dan terlihat adanya kecenderungan (trend) bahwa suhu terus menaik dari tahun ke tahun dengan kenaikan sekitar $0,023^{\circ} \mathrm{C} /$ tahun atau $0,23^{\circ} \mathrm{C} /$ dekade. Kecenderungan kenaikan suhu di WTP Pulau Pieh lebih rendah dibandingkan dengan seluruh perairan Indonesia, yakni sebesar $0,36^{\circ} \mathrm{C}$ /dekade.

Tabel 2. Dinamika SPL malam hari dari citra satelit Aqua-MODIS untuk perairan TWP Pulau Pieh.

Table 2. The night time SST dynamics of TWP Pieh Island ackquired from Aqua-MODIS Satellite

\begin{tabular}{|c|c|c|c|c|c|c|c|c|c|c|c|c|c|c|c|c|}
\hline Month & 2003 & 2004 & 2005 & 2006 & 2007 & 2008 & 2009 & 2010 & 2011 & 2012 & 2013 & 2014 & 2015 & 2016 & 2017 & $\begin{array}{c}\text { Mean } \\
\text { Monthly }\end{array}$ \\
\hline Jan. & 29.1 & 28.1 & 29.6 & 28.8 & 29.6 & 27.2 & 29.0 & 29.4 & 29.0 & 28.7 & 28.6 & 29.4 & 29.7 & 30.5 & 28.7 & 28.84 \\
\hline Feb. & 29.7 & 27.7 & 29.9 & 29.7 & 28.9 & 28.9 & 28.9 & 29.1 & 27.4 & 29.6 & 29.1 & 29.4 & 29.5 & 30.0 & 29.3 & 29.20 \\
\hline Mar. & 29.8 & 29.3 & 29.7 & 29.1 & 28.9 & 28.6 & 29.3 & 29.4 & 28.9 & 29.1 & 29.5 & 30.0 & 28.5 & 29.4 & 29.4 & 29.30 \\
\hline Apr. & 29.7 & 29.6 & 29.9 & 29.4 & 29.3 & 29.4 & 29.6 & 30.0 & 29.0 & 30.0 & 29.6 & 28.2 & 29.6 & 29.2 & 29.3 & 29.38 \\
\hline May & 29.6 & 29.2 & 29.7 & 29.7 & 29.1 & 29.1 & 30.1 & 29.6 & 29.5 & 29.6 & 29.2 & 29.3 & 30.2 & 29.9 & 29.8 & 29.68 \\
\hline Jun. & 29.0 & 29.2 & 29.1 & 29.2 & 29.4 & 28.7 & 29.7 & 29.5 & 29.3 & 29.2 & 29.5 & 29.5 & 30.0 & 30.1 & 29.4 & 29.38 \\
\hline Jul. & 29.0 & 29.1 & 28.9 & 28.8 & 29.1 & 28.6 & 29.3 & 29.8 & 29.0 & 28.9 & 29.1 & 29.1 & 29.5 & 30.0 & 29.5 & 29.27 \\
\hline Aug. & 29.1 & 29.1 & 29.1 & 27.6 & 28.7 & 29.2 & 29.2 & 29.8 & 29.0 & 29.1 & 29.1 & 28.7 & 29.1 & 29.7 & 29.2 & 29.08 \\
\hline Sep. & 29.1 & 29.7 & 28.2 & 27.5 & 27.6 & 28.7 & 27.5 & 29.3 & 28.1 & 29.5 & 29.8 & 28.4 & 28.6 & 26.6 & 29.7 & 29.18 \\
\hline Oct. & 25.9 & 27.7 & 27.7 & 27.7 & 28.9 & 29.0 & 29.0 & 27.1 & 29.1 & 29.0 & 28.5 & 27.9 & 29.2 & 27.7 & 27.9 & 28.11 \\
\hline Nov. & 29.4 & 29.2 & 27.1 & 27.5 & 27.2 & 28.1 & 29.1 & 28.7 & 29.0 & 29.4 & 28.6 & 27.2 & 28.7 & 28.2 & 28.6 & 28.52 \\
\hline Dec. & 29.4 & 28.9 & 29.6 & 27.2 & 26.7 & 27.5 & 29.2 & 29.0 & 28.6 & 26.8 & 29.0 & 28.7 & 29.2 & 29.7 & 27.1 & 27.78 \\
\hline $\begin{array}{l}\text { Mean } \\
\text { Yearly }\end{array}$ & 29.1 & 28.9 & 29.0 & 28.5 & 28.6 & 28.6 & 29.2 & 29.2 & 28.8 & 29.1 & 29.1 & 28.8 & 29.3 & 29.3 & 29.0 & \\
\hline
\end{tabular}


Oseanologi dan Limnologi di Indonesia 2020 5(1): 1-18

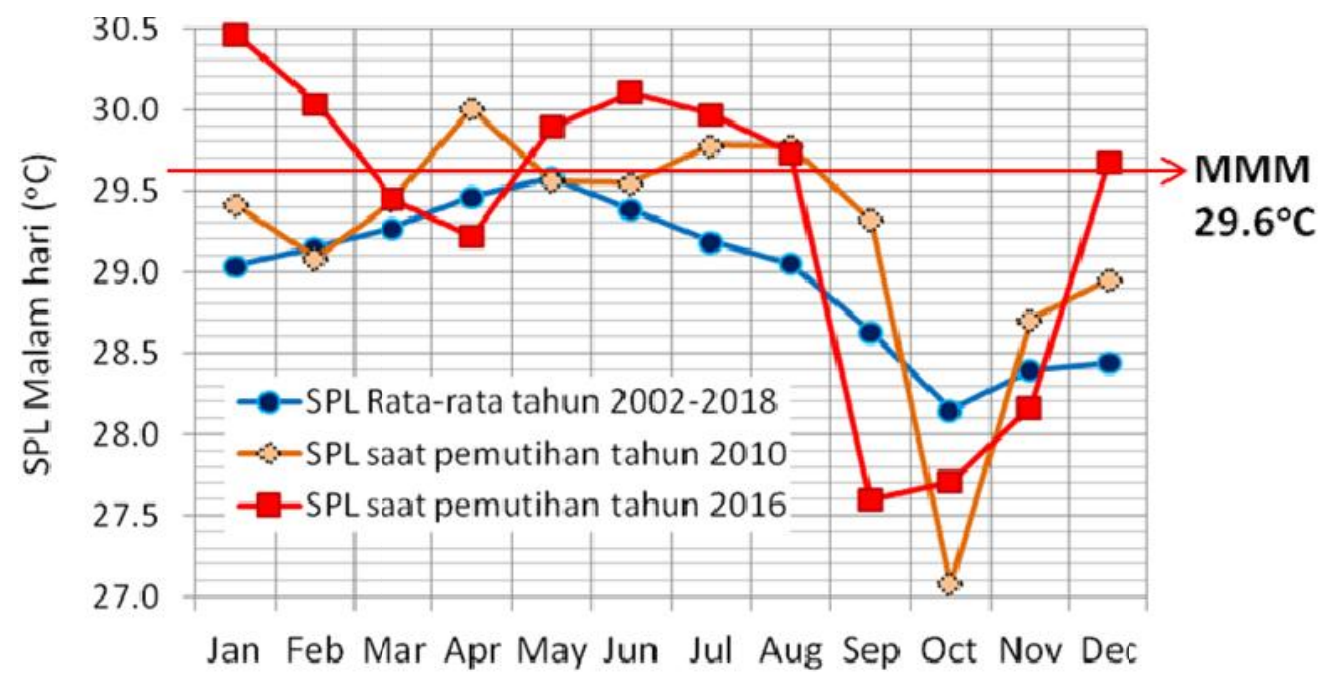

Gambar 6. Pola SPL di TWP Pulau Pieh pada kondisi normal (2002-2017) dengan SPL MMM 29,6 $6^{\circ} \mathrm{C}$ dan saat kejadiaan pemutihan karang tahun 2010 dan 2016.

Figure 6. The SST patern at TWP Pieh Island at normal condition (2002-2017) with MMM of $29.6{ }^{\circ} \mathrm{Cand}$ during the coral bleaching events of 2010 and 2016.

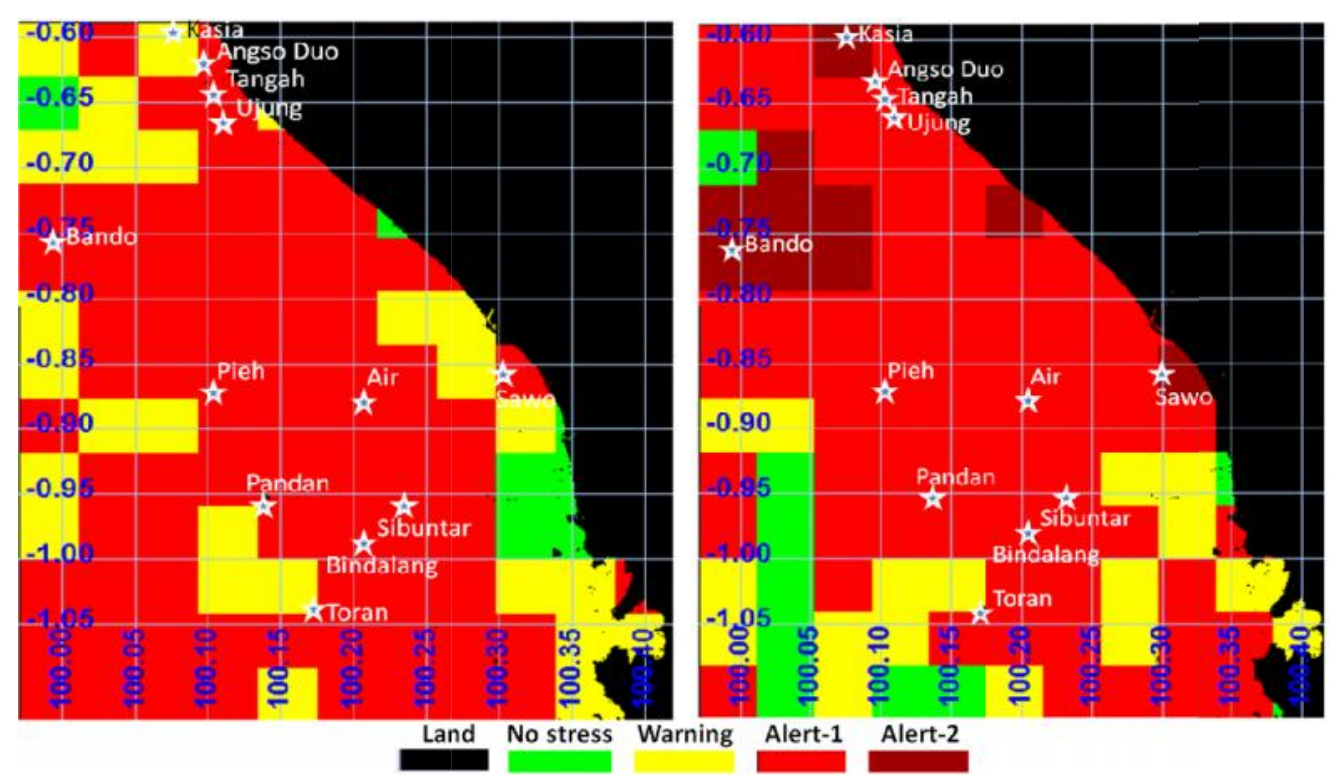

Gambar 7. Peta sebaran DHW di TWP Pulau Pieh bulan Januari 2016 (kiri) dan Mei-Juni 2016 (kanan).

Figure 7. The distribution map of DHW at TWP Pieh Island of January 2010 (left) and May -June 2016 (right). 
Wouthuyzen et al.
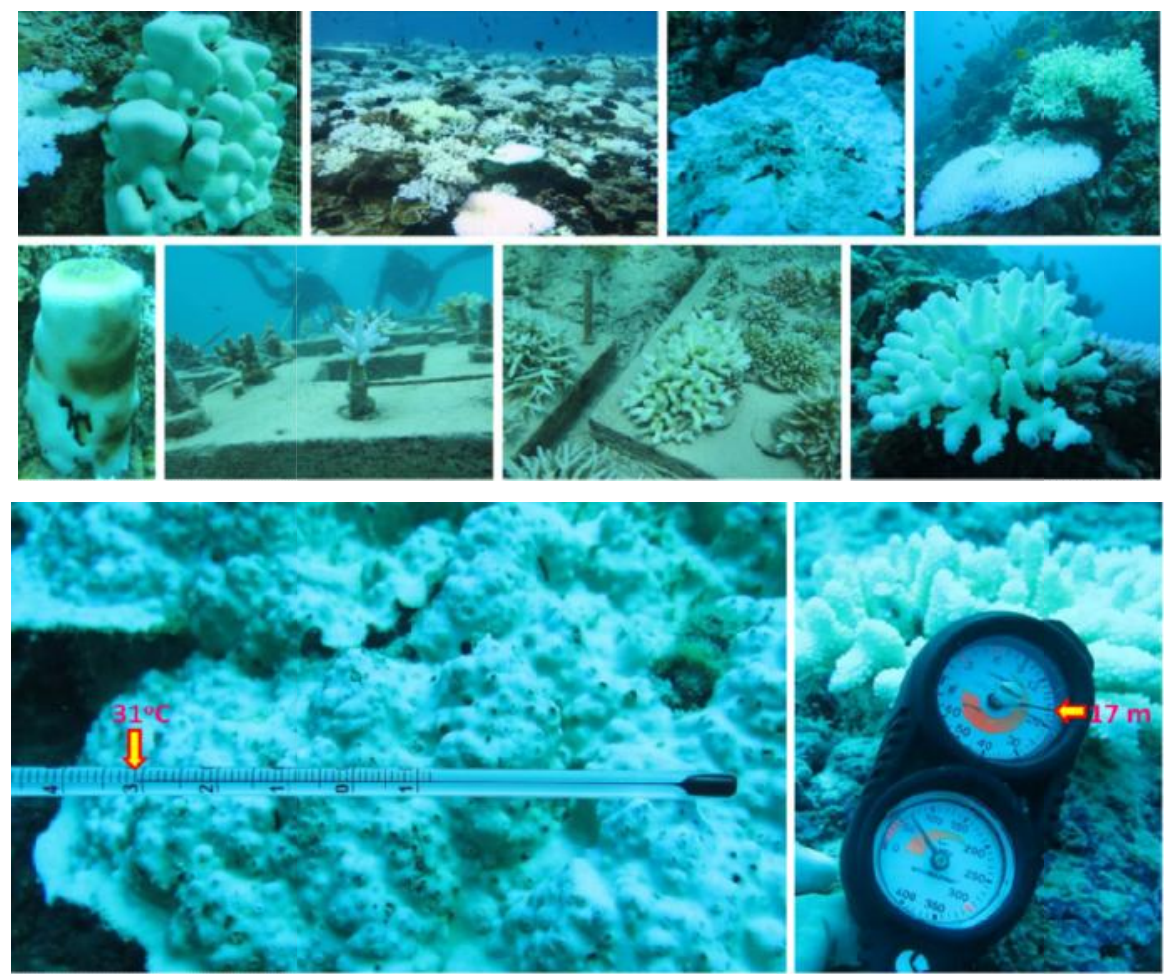

Gambar 8. Foto pemutihan karang di Pulau Pieh dan Toran, SPL mencapai $31^{\circ} \mathrm{C}$ hingga kedalaman $17 \mathrm{~m}$. Figure 8. Photos of bleached coral in Pieh and Toran Islands, SST reach $31^{\circ} \mathrm{C}$ and depth of $17 \mathrm{~m}$.
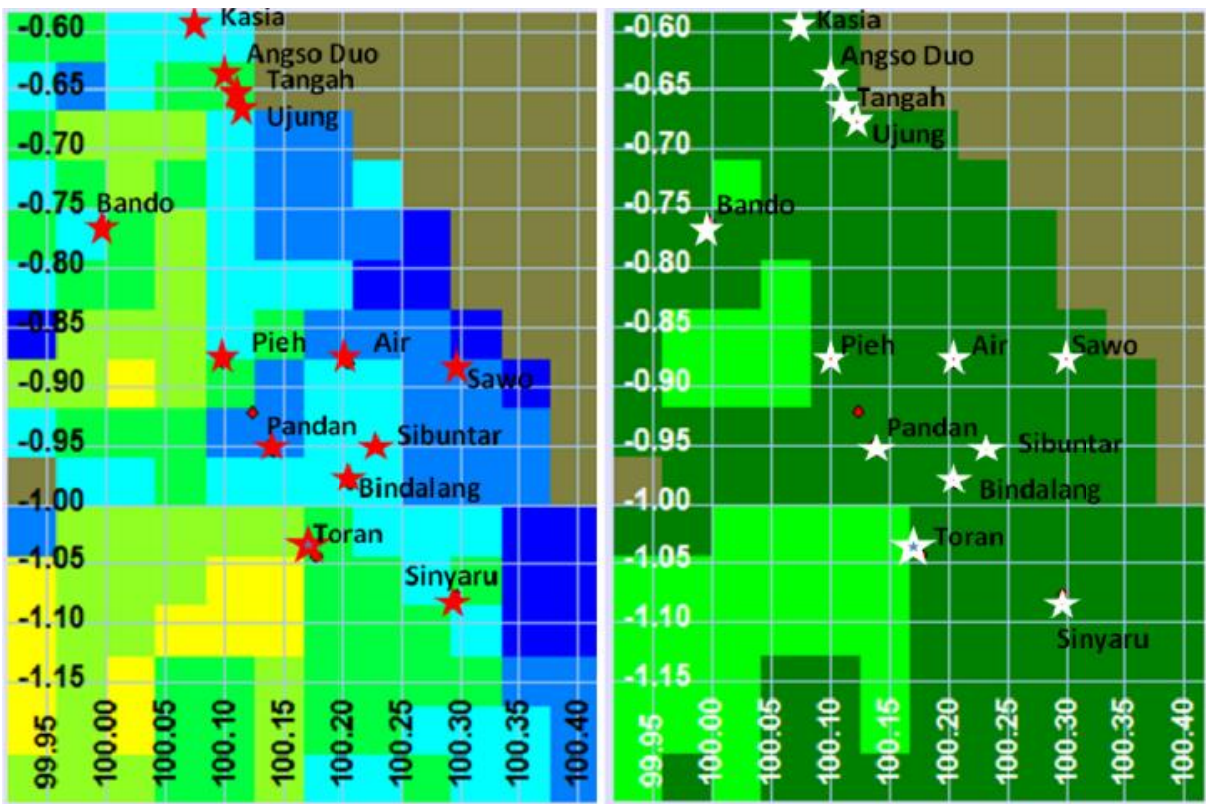

Gambar 9. SPL dari citra satelit MODIS yang bersamaan dengan survei lapangan pada bulan Juni (kiri) dan Juli 2018 (kanan), yang menunjukkan tidak ada stress suhu terhadap koral.

Figure 9. SST derived using MODIS satellite of June (left) and July (right), which coincides with field survey. These SST maps did not show temperature stress on corals. 
Oseanologi dan Limnologi di Indonesia 2020 5(1): 1-18

Tabel 3. Pengukuran kualitas air sekitar perairan TWP Pulau Pieh selama survei lapangan (Juni-Juli 2018)

Table 3. Water quality measurement around TWP Pieh Island during field survei (June-July 2018)

\begin{tabular}{|c|c|c|c|c|c|c|c|c|c|c|c|c|}
\hline NO & Station & Sampling sites & Longitude & Latitude & Time & $\begin{array}{c}\text { Temperature } \\
\left({ }^{\circ} \mathrm{C}\right)\end{array}$ & $\begin{array}{c}\text { DO } \\
(\mathrm{mg} / \mathrm{L})\end{array}$ & $\begin{array}{l}\text { Conductivity } \\
(\mathrm{mS} / \mathrm{cm})\end{array}$ & TDS $(\mathrm{g} / \mathrm{L})$ & $\begin{array}{c}\text { Salinity } \\
\text { (PSU) }\end{array}$ & $\mathrm{pH}$ & $\begin{array}{c}\text { Transparency } \\
\text { (m) }\end{array}$ \\
\hline 1 & PICR-01 & Pulau Bando & 99.99872 & -0.75914 & $6 / 27 / 2018$ & 29.37 & 5.10 & 56.63 & 34.00 & 34.30 & 8.42 & 15.00 \\
\hline 2 & PICR-02 & Pulau Bando & 99.99798 & -0.76492 & $6 / 27 / 2018$ & 29.30 & 6.07 & 56.73 & 34.09 & 34.41 & 8.43 & 17.00 \\
\hline 3 & PICR-03 & Pulau Pieh & 100.10247 & -0.87239 & $6 / 27 / 2018$ & 29.50 & 5.90 & 57.07 & 34.21 & 34.53 & 8.44 & 23.00 \\
\hline 4 & PICR-04 & Pulau Pieh & 100.10010 & -0.87742 & $6 / 27 / 2018$ & 29.40 & 5.07 & 57.27 & 34.38 & 34.64 & 8.45 & 30.00 \\
\hline 5 & PICR-05 & Pulau Air & 100.20444 & -0.87294 & $6 / 27 / 2018$ & 29.25 & 5.67 & 55.98 & 33.37 & 33.97 & 8.40 & 9.50 \\
\hline 6 & PICR-06 & Pulau Air & 100.20550 & -0.87712 & $6 / 27 / 2018$ & 29.12 & 5.80 & 55.65 & 33.51 & 33.71 & 8.39 & 8.00 \\
\hline 7 & PICR-07 & Pulau Pandan & 100.13861 & -0.94672 & $6 / 27 / 2018$ & 29.50 & 5.67 & 57.17 & 34.26 & 34.58 & 8.45 & 15.00 \\
\hline 8 & PICR-08 & Pulau Pandan & 100.14110 & -0.95263 & $6 / 27 / 2018$ & 29.50 & 5.90 & 57.43 & 34.41 & 34.73 & 8.46 & 17.00 \\
\hline 9 & PICR-09 & Gosong Pandan & 100.12414 & -0.91858 & $6 / 27 / 2018$ & 29.50 & 5.67 & 57.17 & 34.26 & 34.58 & 8.45 & 15.00 \\
\hline 10 & PICR-10 & Pulau Bindalang & 100.20792 & -0.97958 & $6 / 26 / 2018$ & 29.53 & 6.30 & 56.96 & 34.10 & 34.37 & 8.40 & 16.00 \\
\hline 11 & PICR-11 & Pulau Toran & 100.17130 & -1.03358 & $6 / 26 / 2018$ & 29.55 & 6.45 & 57.48 & 34.37 & 34.44 & 8.40 & 18.50 \\
\hline 12 & PICR-12 & Pulau Toran & 100.17803 & -1.04089 & $6 / 26 / 2018$ & 29.50 & 6.33 & 57.32 & 34.32 & 34.45 & 8.36 & 17.50 \\
\hline 13 & PICR-13 & Pulau Sinyaru & 100.29692 & -1.07275 & $6 / 26 / 2018$ & 29.22 & 6.80 & 56.18 & 33.80 & 34.09 & 8.40 & 9.50 \\
\hline 14 & PICR-14 & Pulau Kasiak & 100.07422 & -0.59492 & $7 / 1 / 2018$ & 29.45 & 5.98 & 57.13 & 34.21 & 33.49 & 8.38 & 7.00 \\
\hline 15 & PICR-15 & Pulau Angso Duo & 100.10014 & -0.63567 & $7 / 1 / 2018$ & 29.57 & 6.20 & 57.47 & 34.33 & 33.71 & 8.44 & 5.50 \\
\hline 16 & PICR-16 & Pulau Ujuang & 100.11214 & -0.66203 & $7 / 1 / 2018$ & 29.75 & 6.28 & 57.97 & 34.52 & 33.90 & 8.45 & 8.00 \\
\hline 17 & PICR-17 & Pulau Tengah & 100.10402 & -0.64759 & $7 / 1 / 2018$ & 29.70 & 6.18 & 57.92 & 34.55 & 34.44 & 8.46 & 6.50 \\
\hline 18 & PICR-18 & Pulau Sawo & 100.30238 & -0.86235 & $6 / 26 / 2018$ & 30.00 & 6.08 & 56.45 & 33.56 & 33.81 & 8.41 & 4.00 \\
\hline \multirow[t]{4}{*}{19} & PICR-19 & Pulau Sibonta & 100.23090 & -0.96052 & $6 / 26 / 2018$ & 29.43 & 6.00 & 56.37 & 33.77 & 34.04 & 8.41 & 15.67 \\
\hline & & & & & Minimum: & 29.12 & 5.07 & 55.65 & 33.37 & 33.49 & 8.36 & 4.00 \\
\hline & & & & & Maximum: & 30.00 & 6.80 & 57.97 & 34.55 & 34.73 & 8.46 & 30.00 \\
\hline & & & & & Average: & 29.48 & 5.97 & 56.97 & 34.11 & 34.22 & 8.42 & 13.56 \\
\hline
\end{tabular}




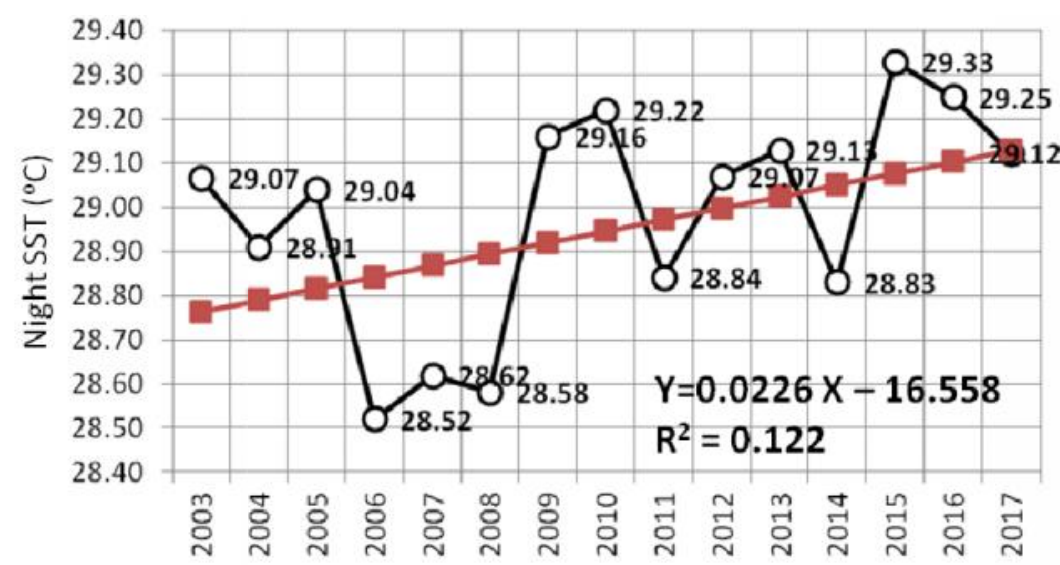

Gambar 10. Pola kecenderungan naiknya SPL di TWP Pieh tahun 2003-2017.

Figure 10. Trend patern in SST increase in the TWP Pieh Island of 2003-2017.

\section{Pembahasan}

\section{Suhu Permukaan Laut dan Pemutihan Karang}

Donner et al. (2005) mengembangkan /menguji algortima pendugaan kejadian pemutihan karang massal menggunakan Global Circulation Model (GCM) dari SPL dan peta sebaran terumbu karang dunia yang mengadopsi pendugaan kejadian pemutihan karang dari coral watch NOAA antara tahun 1985-2002 untuk seribu lokasi terumbu karang. Algoritma tersebut lalu dipakai untuk menentukan frekuensi kejadian pemutihan karang dan adapatasi yang dibutuhkan karang dan simbionnya terhadap dua skenario emisi karbon berbeda antara tahun 1980-2100 dari: (1). US National Center for Atmospheric Research's PCM, dan (2). UK Hadley Centre's HadCM3. Hasil Kajian Donner et al. (2005) menunjukan bahwa kejadian pemutihan karang dapat terjadi setiap tahun atau setiap dua tahun untuk sebagian besar terumbu karang dunia 30-50 tahun ke depan, jika toleransi-suhu pada karang tidak dapat mengikuti kenaikan suhu sebesar 0,2$1,0^{\circ} \mathrm{C} /$ dekade. Selanjutnya dikatakan bahwa variabilitas geografis menyebabkan adaptasi termal pada karang berbeda-beda, misalnya karang di Mikronesia dan Polinesia barat (Samudra Pasifik) termasuk perairan Indonesia dan sisi Sumatra barat (TWP Pulau Pieh) akan lebih rentan terhadap kenaikan SPL.

Kejadian pemutihan karang akibat dampak kenaikan SPL tinggi di perairan Indonesia relatif hanya berlangsung dalam waktu pendek sekitar 3-4 bulan (Maret-Juni), kecuali di TWP Pulau Pieh tahun 2016 (Januari-Februari). Hal ini sejalan dengan pengamatan Heron et al. (2016) di Pasifik dan perairan Asia Tenggara, khususnya di sekitar Pulau Sulawesi yang memperlihatkan penaikkan SPL umumnya berlangsung hanya sekitar tiga bulan berturut-turut (April-Juni). Pada bulan-bulan selanjutnya (Juli-Februari), dominasi SPL perairan Indonesia lebih rendah dari MMM (Gambar 3 dan 6). Hal ini disebabkan adanya pengaruh upwelling musiman di perairan Indonesia, seperti di pantai selatan Jawa, Bali, NTB, NTT, di Laut Banda, Seram, Maluku, Sulawesi, Halmarera, dan laut di sekitarnya. Fenomena upwelling berfungsi sebagai mitigasi alami dari bencana/ancaman kejadian pemutihan karang, karena suhu laut saat upwelling menjadi rendah $\left(<27^{\circ} \mathrm{C}\right)$, jauh di bawah suhu MMM (Wouthuyzen et al., 2015). Disamping itu, adanya jeda waktu (keterlambatan) antara awal kenaikan SPL dan kejadian pemutihan karang di perairan Indonesia, karena adanya siklus monsun Asia Tenggara dan variabilitas inter annual yang relatif tinggi di Samudra Pasifik khatulistiwa yang berkaitan dengan fenomena El Niño-Southern Oscillation. Jadi, pemahaman tentang pola spasial dan waktu pada saat awal karang mulai mengalami tekanan dapat menginformasikan para pengelola/pemerhati lingkungan untuk bersiapsiap terhadap kejadian pemutihan karang yang akan terjadi dalam skala yang lebih besar (Heron et al., 2016).

Walaupun sedikitnya sudah empat kali kejadian pemutihan karang yang berskala dunia (global), namun informasi tentang frekuensi kejadian pemutihan karang sebelum tahun 1979 masih sangat sedikit (Kamenos \& Hennige, 2018). Sebenarnya kejadian pemutihan karang telah berlangsung lama bahkan sebelum era revolusi industri yang diasumsikan bahwa emisi karbon di atmosfir masih jauh lebih rendah dari sekarang, seperti yang diungkapkan dari hasil penelitian Kamenos and Hennige (2018) tentang konstruksi ulang empat abad kejadian pemutihan karang yang disebabkan peningkatan suhu di Great Barrier Reef, Australia menggunakan inti pemboran dari karang Porites spp. 
Hasil kajian mereka menunjukkan ada tiga frekuensi kecenderungan kejadian pemutihan karang, yaitu: (1) kejadian yang semakin meningkat antara tahun 1620 -1753 (6 kali kejadian); (2) kejadian menurun antara tahun 1753-1820 (satu kali kejadian), dan (3) kejadian meningkat kembali dari tahun 1820 hingga 2001. Dekade 1890 dan 1750 tercatat sebagai dekade dengan frekuensi kejadian pemutihan karang yang tinggi. Selanjutnya, berdasarkan hasil kajian Kamenos and Hennige (2018) yang menunjukkan bahwa kejadian pemutihan karang telah berlangsung sejak 4 abad lalu dan ditunjang pula oleh hasil kajian Donner et al. (2005), maka dapat diharapkan bahwa karang perairan Indonesia memiliki resiliensi tinggi terhadap fenomena pemutihan karang akibat naiknya suhu laut. Meskipun demikian resiliensi karang tidak saja ditentukan oleh kenaikan suhu laut, melainkan oleh faktor lainnya, tetapi kenaikan suhu laut (SPL) merupakan faktor yang paling dominan.

\section{Resiliensi}

Berdasarkan hasil kajian Donner et al. (2005), sebenarnya terumbu karang perairan Indonesia memiliki resiliensi yang relatif lebih baik/tinggi, karena kecenderungan kenaikan SPL per dekade perairan Indonesia hanya sebesar $0,36^{\circ} \mathrm{C}$ (Gambar 6), sehingga karang bisa memulihkan dirinya, apalagi di beberapa perairan lokal kecenderungan kenaikan SPL per dekade lebih rendah, seperti di TWP Pulau Pieh sebesar $0,23^{\circ} \mathrm{C}$ (Gambar 10 ) dan $0,21^{\circ} \mathrm{C}$ untuk perairan Pulau Sulawesi (Heron et al., 2016) serta 0,17$0,18^{\circ} \mathrm{C}$ untuk 78 lokasi terumbu karang di perairan Asia Tenggara, Samudra Pasifik dan Hindia termasuk periran Indonesia antara tahun 19852016 (Eakin et al., 2018).

Resiliensi koral yang relatif tinggi di TWP Pulau Pieh juga ditunjukkan dari hasil monitoring persentasi tutupan terumbu karang hidup (Corvianawatie et al., 2018; Gambar 11) yang selalu dapat memulihkan dirinya, walaupun sudah terpapar dua kali periode kejadian pemutihan yang berulang dan panjang pada tahun 2010 dan 2015-2016 (Tabel 2). Setelah kejadian pemutihan karang tahun 2010, persentasi tutupan karang hidup naik kembali dari $24,1 \%$ menjadi $44,4 \%$ di tahun 2015, namun kembali turun ke $28,4 \%$ pada kejadian pemutihan kuat pada tahun 2016 dan kembali pulih serta meningkat tutupannya pada tahun 2018 walaupun hanya sekitar $3 \%$ dari $28,5 \%$ menjadi $31,3 \%$. Sejalan dengan pemantauan Corvianawatie et al. (2018), kajian Wouthuyzen et al. (2019) menggunakan citra resolusi menengah $(10 \mathrm{~m} \times 10 \mathrm{~m})$ satelit Sentinel-2A juga memperlihatkan bahwa ada kecenderungan penurunan luasan terumbu karang terdampak kejadian pemutihan tahun 2016 dari 9,48 ha berkurang menjadi 5,61 ha pada tahun 2018 di Pulau Toran, TWP Pulau Pieh.

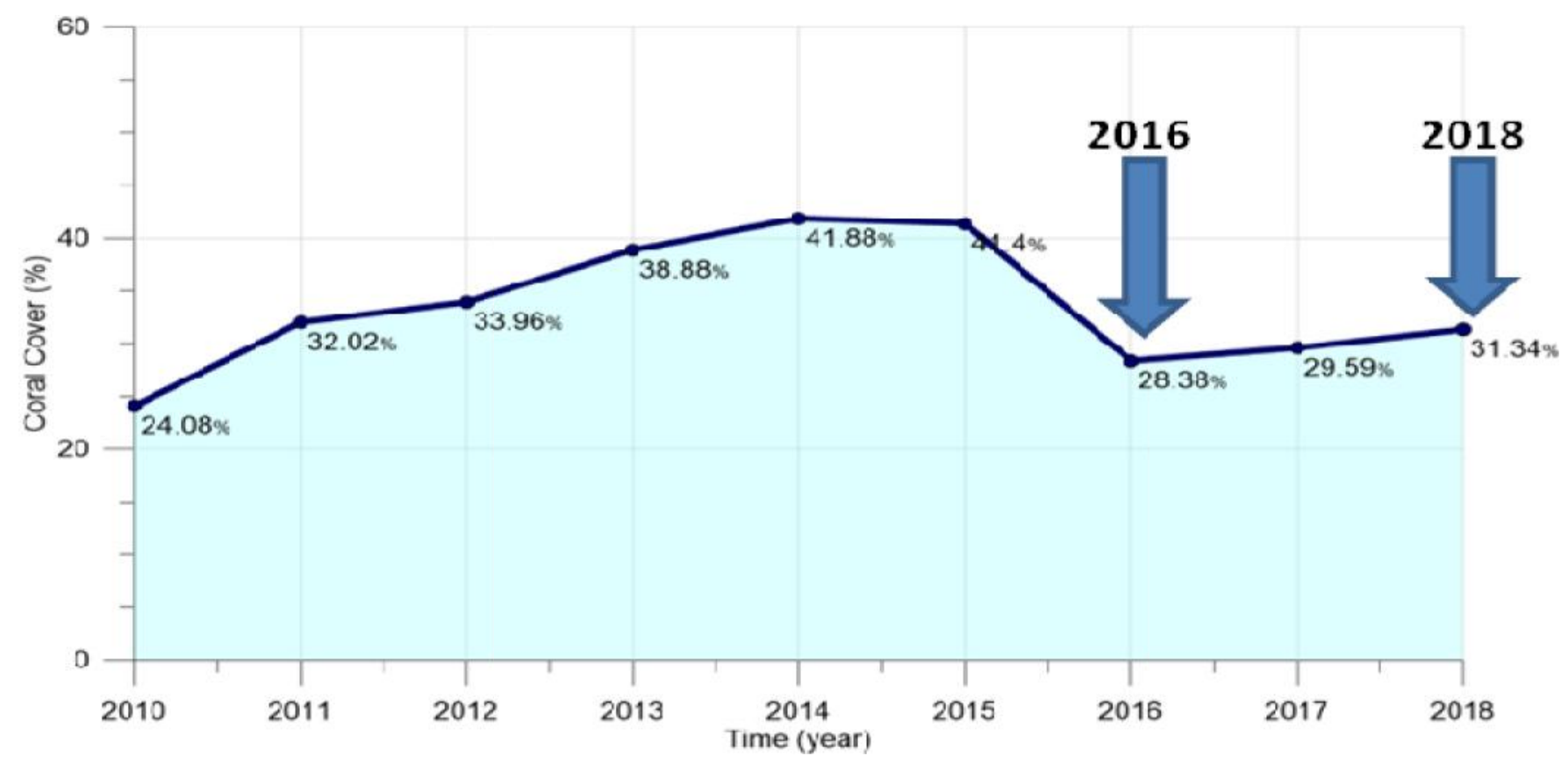

Gambar 11. Pemulihan koral di TWP Pulau Pieh setelah 2 kali terpapar kejadian pemutihan karang tahun 2010 dan 2016 (Corvianawatie et al., 2018).

Figure 11. Coral recovery in the TWP Pieh Island after 2 times exposed to coral bleaching events in 2010 and 2016 (Corvianawatie et al., 2018). 
McClanahan et al. (2012) mengembangkan 11 faktor kunci yang menentukan resiliensi terumbu karang, yaitu : (1) Spesies karang yang tahan terhadap kenaikan suhu, (2) Variabilitas suhu; (3) Pencemaran nutrien yang meningkatkan eutrofikasi perairan; (4) Sedimentasi; (5) Keanekaragaman karang; (6) Biomassa ikan herbivora; (7) Dampak fisik dari aktivitas manusia; (8) Penyakit karang; (9) Makro algae; (10) Rekruitmen karang; dan (11) Tekanan dari penangkapan ikan. Selanjutnya dikatakan bahwa kelimpahan spesies karang yang tahan terhadap naiknya suhu laut dan variabilitas suhu masa lalu merupakan resistensi karang tertinggi terhadap perubahan iklim, sementara tingkat rekrutmen karang, dan kelimpahan makroalga serta biomas ikan herbivora paling berpengaruh dalam proses pemulihan terumbu karang. Berkaitan dengan kriteria tersebut di atas, secara kualitatif tampaknya resiliensi karang di seluruh pulau TWP Pulau Pieh (Pulau Bando, Pieh, Air, Pandan, dan Toran), lebih ditentukan oleh faktor spesies karang yang tahan terhadap kenaikan SPL dan variabilitasnya (Tabel 2, Gambar 6), sedangkan faktor lainnya, yakni pencemaran /nutrien dan sedimentasi, keaneka-ragaman jenis karang, dan aktivitas manusia tampaknya tidak berpengaruh nyata (Tabel 3).

TWP Pulau Pieh memiliki kualitas perairan yang baik bagi kehidupan karang, dimana nutrien dan sedimentasi berada dalam konsentrasi rendah, dan kecerahan perairan yang tinggi (7$30 \mathrm{~m}$ dengan nilai rata-rata $13 \mathrm{~m}$ ), karena terletak relatif jauh dari sumber cemaran. Disamping itu, karena sebagian pulau-pulau di TWP ini (Pulau Bando dan Pieh) diperuntukkan sebagai zona inti yang tidak bisa diganggu, maka ganguan fisik akibat aktivitas manusia, seperti penangkapan ikan yang tidak ramah lingkungan juga rendah. Meskipun demikian, resiliensi karang di TWP Pulau Pieh berkurang karena populasi hewan Bulu Seribu Acanthaster planci yang meledak dan berlangsung lama sejak tahun 2017 (Gambar 12) di Pulau Toran dan Pieh, selain ada juga penyakit karang, yaitu blackband disease yang disebabkan oleh virus yang dipicu oleh nutrient tinggi dan peningkatan suhu laut. Pemangsaan hewan ini membuat karang menjadi putih dengan tingkat keparahan mungkin bisa lebih tinggi dari akibat anomali SPL, karena karang mati total, sedangkan pada kejadian pemutihan karang akibat anomali SPL, karang masih dapat pulih kembali jika tingkat keparahannya rendah (DHW $<8^{\circ} \mathrm{C}$ minggu). Meledaknya populasi Acanthaster planci sehingga tutupan karang menjadi rendah dilaporkan pula di pulau-pulau kecil seperti, Mo'orea reef, French Polynesia (Guest et al., 2018) dan di Taema Bank, Tutuila, American Samoa (Schumacher et al., 2018) yang bersamaan dengan kejadian pemutihan karang.
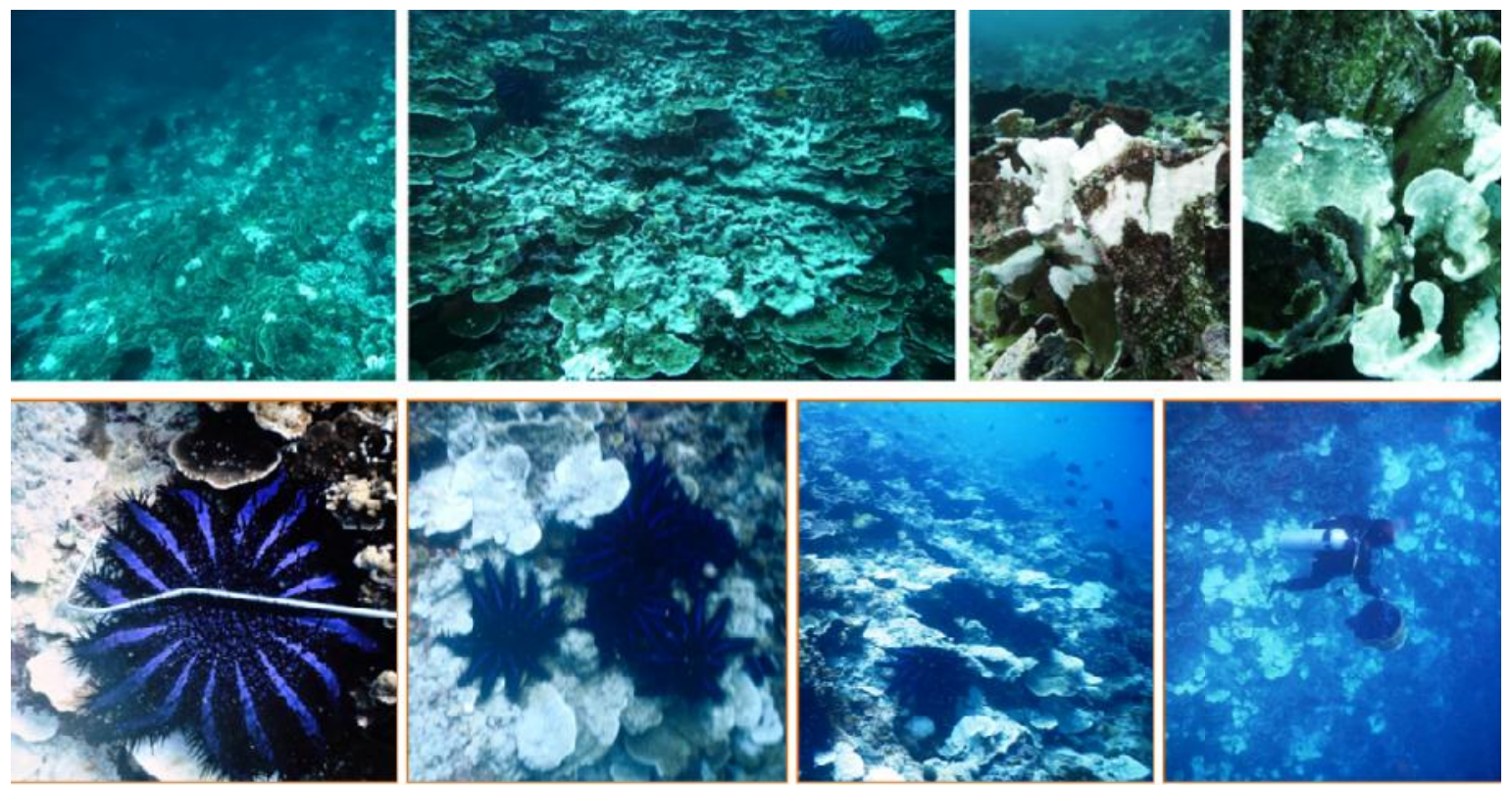

Gambar 12 Meledaknya populasi hewan Bulu Seribu, Acanthaster planci di TWP Pulau Pieh, yaitu di Pulau Toran (atas) dan Pulau Pieh (bawah) tahun 2017

Figure 12. the explosion of crown-of-thorns starfish,Acanthaster planci population in the TWP Pieh Islands: (top) Toran Island and (bellow) Pieh Island in 2017. 


\section{Mitigasi}

Terkait dengan mitigasi kejadian pemutihan karang, belum ada cara yang benarbenar bisa diterapkan untuk menghindari dari fenomena tersebut. Meskipun demikian, gagasan dari kajian Guest et al. (2018) dapat digunakan untuk mengembangkan kerangka kerja dalam mengidentifikasi dan mencirikan "oasis" terumbu karang yang dideskripsikan sebagai suatu lokasi /situs/habitat karang yang menonjol/khas karena kemampuannya untuk bertahan, menghindari diri, melawan, atau bangkit dari berbagai gangguan, dimana salah satu gangguan tersebut adalah kejadian pemutihan karang.

Ide lainnya digagas oleh Van Oppen et al. (2018), yaitu mengembangkan stok karang yang memiliki tingkat ketahanan/toleransi stress terhadap naiknya suhu laut tinggi secara global melalui percepatan proses yang terjadi secara alami (aklimatisasi). Pendekatan ini dikenal sebagai evolusi yang dibantu manusia (humanassisted evolution). Lebih lanjut pendekatan lainnya yang dapat dilakukan, namun agak sulit adalah memodifikasi komunitas mikroskopik simbion dengan cara menginokulasi karang pada stadia kehidupan awal dengan simbion mikroskopik yang toleran terhadap stres suhu laut tinggi (Van Oppen et al., 2018). Gagasan lainnya lagi yang mirip adalah memindahkan (translocation) karang dari perairan Gulf (sisi Iran) yang terkenal memiliki jenis karang yang sangat tahan terhadap suhu laut tinggi $\left(>10^{\circ} \mathrm{C}\right.$ pada musim panas) keluar perairan gulf agar diperoleh karang yang memiliki ketahanan tinggi terhadap suhu laut. Budidaya/transplantasi karang di perairan Gulf juga layak dilakukan untuk membantu mempertahankan populasi spesies karang, melestarikan genomnya dan kapasitas adaptifnya atas ancaman kejadian stres termal di masa depan (Coles \&Riegl, 2012).

Pengelola/pemerhati terumbu karang tidak dapat melawan pemanasan global melalui mitigasi pada skala lokal (Chollett et al., 2014), namun kita dapat menggunakan data dan informasi tentang segala aspek karang dan kejadian pemutihan karang dari berbagai sumber untuk merencanakan pengelolaan yang maksimal terhadap sistem karang kita. Oleh karenanya berbagai ide/gagasan seperti yang dicontohkan di atas dapat kita gunakan, modifikasi dan kembangkan sehingga menjadi lebih baik.

\section{Kesimpulan}

Taman Wisata Perairan Pulau Pieh telah mengalami kejadian pemutihan karang yang dipicu oleh pemanasan global yang panjang dan berulang-ulang (sedikitnya 2-3 kali) serta kuat (DHW 4 hingga $>8{ }^{\circ} \mathrm{C}$-minggu) dan dengan tingkat keparahan Alert-1 (sebagian karang mengalami pemutihan) serta keparahan Alert-2 (karang mengalami pemutihan yang merata dan luas, dan bahkan ada yang mati). Walaupun demikian, kejadian pemutihan yang berdurasi pendek (tiga bulanan; April-Juni) serta kecenderungan tingkat penaikan SPL dalam jangka waktu panjang (15 tahun) yang hanya sebesar 0,23 ${ }^{\circ} \mathrm{C} /$ dekade menandakan bahwa karang di TWP ini memiliki resiliensi tinggi untuk memulihkan diri dari kejadian pemutihan karang selama fenomena El-Nino berlangsung. Faktor kunci yang mendukung resiliensi karang tinggi di TWP ini mencakup polusi, nutrien, sedimentasi dan aktivitas manusia dalam pemanfaatan sumber daya ikan yang rendah. Sebaliknya, faktor kunci yang melemahkan adalah meledaknya populasi Acanthaster planci yang berlangsung lama dan ditemukannya penyakit karang. Secara kuantitatif, ke depan, penghitungan dan pemetaan bobot dan skor dari berbagai faktor kunci resiliensi karang yang berkaitan dengan dampak langsung dari pemutihan karang serta proses yang dapat memulihkan karang (tingkat rekrutmen karang, kelimpahan makroalga serta biomas ikan herbivora) di masing-masing lokasi pengamatan baik di pulau-pulau yang terletak di dalam kawasan TWP Pulau Pieh dan di luar kawasan perlu dilakukan. Data yang dihasilkan bisa digunakan untuk pemantauan, evaluasi dan pengelolaan serta mitigasi kejadian pemutihan karang yang lebih baik dan spesifik untuk setiap lokasi pengamatan TWP Pulau Pieh.

\section{Persantunan}

Hasil kajian ini didukung dari dana peneltian DDRG-LIPI tahun 2018. Kami sampaikan terima kasihkepada Bapak kepala TWP Pulau Pieh beserta stafnya, para peneliti di LRSDKP, KKP, Teluk Bungus, Padang dan teman-teman Minang Bahari, Padang yang membantu pekerjaan di lapangan. Analisis dan visualisasi data SPL yang digunakan dalam tulisan ini diperoleh dari sistem data online Giovanni (Geospatial Interactive Online Visualization and Analysis Infra-structure) yang dikembangkan dan dipelihara oleh GES DISC. (Goddard Earth Sciences Data and Information Services Center), NASA. Untuk itu kami sampaikan rasa terima kasih atas penyediaan data tersebut. Apresiasi kami sampaikan pula kepada para penelaah naskah kami (reviewer) yang telah memberikan koreksi/masukan yang berharga sehingga tulisan ini menjadi lebih baik. 


\section{Daftar Pustaka}

Anonymous (2001). Philippine Coastal Management Guidebook No. 5: Managing Coastal Habitats and Marine Protected Areas. Coastal Resource Management Project of the Department of Environment and Natural Resources, Cebu City, Philippines, $106 \mathrm{p}$.

Baker, A. C., Glynn, P. W., \& Riegl, B. (2008). Climate change and coral reef bleaching: Anecological assessment of long-term impacts, recovery trends and future outlook. Estuarine Coastal and Shelf Science, 80(4), 435-471.

Berkelmans, R., De'ath, G., Kininmonth, S., \& Skirving, W. J.(2004). A comparison of the 1998 and 2002 coral bleaching events on the Great Barrier Reef: spatial correlation, patterns, and predictions. Coral Reefs 23, 74-83. https://doi.org/10.1007/s00338-0030353-y

Brown, B.E. (1997). Coral bleaching: causes and consequences. Coral Reefs, 16, S129-S138.

Bruno, J.F., Ciddon, C.E., Witman, J.D., Colin, P.L. and Toscano, M.A. (2001). El Niño related coral bleaching in Palau, Western Caroline Islands. Coral Reefs 20, 127-136. https://doi.org/10.1007/s003380100151

Chollett, I., Enríquez, E.\& Mumby, P.J. (2014). Redefining Thermal Regimes to Design Reserves for Coral Reefs in the Face of Climate Change. PLoS ONE, 9(10), e110634. https://doi.org/10.1371/journal .pone.0110634

Coles, S.L., \& Brown, B.E. (2003). Coral bleaching capacity for acclimatization and adaptation. Advances in Marine Biology, 46, 183-223.

Coles, S.L., \& Riegl, B.M. (2013). Thermal tolerances of reef corals in the Gulf: A review of the potential for increasing coral survival and adaptation to climate change through assisted translocation. Marine Pollution Bulletin, 72(2), 323-332.

https://doi.org/10.1016/j.marpolbul.2012.09 .006

Corvianawatie, C., Abrar, M., Wouthuyzen, S., Darmawan, Kusumo, S., Samsuardi, Yennafri, Salatalohi, A., Hanif, A., Permana, S., Arrafat, M. Y., \& Tanto, T.A. (2018). The ocean-atmospheric condition around Pieh Islands - Western Sumatra, Indonesia and its role on coral reef resilience. Proceedings of IOP Conf. Ser.: Earth and Environ. Sci. 200, 012063. https://doi.org/10.1088/1755-1315/200/1/ 012063

Donner, S. D., Skirving, W. J., Christopher, M.L., Oppenheimer, M., \& Hoegh-Gulberg, O. (2005). Global assessment of coral bleaching and required rates of adaptation under climate change. Global Change Biology, 11(12); 2251-2265. https://doi.org/10.1111/j.1365-2486.2005. 01073.x

Douglas, A. E. (2003). Coral bleaching - how and why?. Marine Pollution Bulletin, 46(4), 385-392.

Eakin, C.M., Nim, C.J., Brainard, R.E., Aubrecht, C., Elvidge, C. Gledhill, K., Muller-Karger, F., Mumby, P.J., Skirving, W.J., Strong, A.E., Wang, M., Weeks, S., Wentz, F., \& Ziskin, D. (2010). Monitoring coral reefs from space. Oceanography, 23(4), 118-133. https://doi. org/10.5670/oceanog.2010.10

Eakin, C.M., Liu, G., Gomez, A.M., De La Cour, J.L., Heron, S.F., Skirving, W.J., Geiger, E.F., Tirak, K.V. \& Strong, A.E. (2016). Global Coral Bleaching 2014-2017? Status and an Appeal for Observations. Reef Encounter 43 31(1), 20-26.

Eakin C.M., Lough J.M., Heron S.F. (2018) Climate Variability and Change: Monitoring Data and Evidence for Increased Coral Bleaching Stress. In: van Oppen M.J.H., Lough J.M. (eds) Coral Bleaching. Ecological Studies, vol 205. Springer, Berlin, Heidelberg. https://doi.org/10.1007/978-3-540-6977564

Goreau, T. J., \& Hayyes, R. L. (1994). Coral bleaching and ocean "hot spots". Ambio, 23, 176-180.

Guest, J.R., Baird, A.H., Maynard, J.A., Muttaqin, E., Edwards, A.J., Campbell, S.J., Yewdall, K., Affendi, Y.A., \& Chou, L.M. (2012). Contrasting patterns of coral bleaching susceptibility in 2010 suggest an adaptive response to thermal stress. PLoS ONE, 7(3), 1-8.

Guest, J.R., Edmunds, P.J., Gates, R.D., Kuffner, I.B., Andersson, A.J., Barnes, B.B., Chollett, I., Courtney, T.A., Elahi, R., Gross, K., Lenz, E.A., Mitarai, S., Mumby, P.J., Nelson, H.R., . Parker, B.A., Putnam, H.M., Rogers, C.S. \& Toth, L.T. (2018). A framework for identifying and characterising coral reef "oases" against a backdrop of degradation. Journal of Applied Ecology, 55(6), 1-11.

https://doi.org/ 10.1111/ 1365-2664.13179 
Hoegh-Guldberg, O.(1999). Climate change, coral bleaching and the future of the world's coral reefs. Marine and Freshwater Research, 50(8), 839-866.

Heron, S. F., Maynard, J. A., van Hooidonk, R., \& Eakin, M. C. (2016). Warming trends and bleaching stress of the world's coral reefs 1985-2012. Scientific Reports, 6, 38402. https:// doi.org/10.1038/srep38402

Ibrahim, N., Mohamed, M., Basheer, A., Ismail, H., Nistharan, F., Schmidt, A., Naeem, R., Abdulla, A., \& Grimsditch, G. (2017). Status of coral bleaching in the Maldives in 2016. Marine Research Centre, Malé, Maldives.

Indian National Centre for Ocean Information Services (INCOIS). 2011. Coral bleaching Alert System. Technical Documentation, INCOIS, Hyderabad.

Liu, G., Strong, A. E.\& Skriving, W. (2003). Remote sensing of sea surface temperatures during 2002 barrier reef coral bleaching. Eos, 84(15), 137-144.

Marshall, P. \& Schuttenberg, H. (2006). A reef manager's guide to coral bleaching. Australia: Great Barrier Reef Marine Park Authority, Townsville.

Maynard, J.A., McKagan, S., Raymundo, L., Johnson, S., Ahmadia, G.N., Johnston, L., Houk, P., Williams, G.J., Kendall, M., Heron, S.F., van Hooidonk, R., Mcleod, E., Tracey, D. \& Planes, S. (2015). Assessing relative resilience potential of coral reefs to inform management. Biological conservation, 192, 109-119.

http://dx.doi.org/10.1016/j/biocon.2015.09. 001

McClanahan, T.R., Donner, S.D., Maynard, J.A., MacNeil, M.A., Graham, N.A.J., Maina, J., Baker, A.C., Alemu, J.B., Beger, M., Campbell, S.J., Darling, E.S., Eakin, C.M., Heron S.F., Jupiter, S.D., Lundquist, C.J., McLeod, E., Mumby, P.J., Paddack, M.J., Selig, E.R \& van Woesik, R. (2012). Prioritizing key resilience indicators to support coral reef management in a changing climate. PLoS ONE, 7(8), e42884. https://doi.org/10.1371/journal.pone.00428 84

McClanahan T.R., Weil E., Baird A.H. (2018) Consequences of Coral Bleaching for Sessile Reef Organisms. In: van Oppen M., Lough J. (eds) Coral Bleaching. Ecological Studies (Analysis and Synthesis), vol 233. Springer, Cham. https://doi.org/10.1007/978-3-319-753935_10
Miranda, R. J., Cruz, I. C. S., \& Leão, Z. M. A. N.(2013). Coral bleaching in the Caramuanas reef (Todos os Santos Bay, Brazil) during the 2010 El Niño event. Latin American Journal of Aquatic Research, 41(2), 351-360.

Mumby, P., \& Edwards, A. (2002). Mapping marine environments with IKONOS imagery: Enhanced spatial resolution can deliver greater thematic accuracy. Remote Sensing of Environment, 82(2-3), 248-257.

Oliver J.K., Berkelmans R., Eakin C.M. (201. Coral Bleaching in Space and Time. In: van Oppen M., Lough J. (eds) Coral Bleaching. Ecological Studies (Analysis and Synthesis), vol 233. Springer, Cham. https://doi.org/10.1007/978-3-319-753935_3

Ompou, E. E., Johan, O., Menkes, C. E., Niño, F., Birol, F., Ouillon, S. and Andréfouët, S. 2017. Coral mortality induced by the 20152016 El-Niño in Indonesia: the effect of rapid sea level fall. Biogeosciences, 14, 817-826. https://doi.org/10.5194/bg-14-817 -2017

Schumacher, B.D., Vargas-Ángel, B. and S.F. Heron. (2018). Identifying coral reef resilience potential in Tutuila, American Samoa based on NOAA coral reef monitoring data. NOAA Special Publication. NMFS-PIFSC-SP-18-03.

https://repository.library.noaa.gov/view/noa a/17371

Van Oppen, M.J.H., Oliver, J.K., Putnam, H.M. \& Gates, R.D. (2015). Building coral reef resilience through assisted evolution. PNAS, 112(8), 2307-2313. https://doi.org/10.1073/pnas.1422301112

Wouthuyzen, S., Abrar, M., \& Lorwens, J. (2015). Pengungkapan kejadian pemutihan karang tahun 2010 di perairan Indonesia melalui analisis suhu permukaan laut. Oseanologi dan Limnologi di Indonesia, 1(3), 305-327.

Wouthuyzen, S., Abrar, M.,\& Lorwens, J. (2018). A comparison between the 2010 and 2016 El-Ninō induced coral bleaching in the Indonesian waters. Proceedings of IOP Conf. Ser.: Earth and Environ. Sci. 118 (012051), 1-15. https://doi.org/10.1088/1755-1315/118/1/ 012051

Wouthuyzen, S., Abrar, M., Corvianawatie, C., Salatalohi, A., Kusumo, S., Yogi, Darmawan, Samsuardi, Yennafri, \& Arafat, M.Y. (2019). The potency of Sentinel-2 satellite for monitoring before, and after coral bleaching events in Marine Recreation 
Wouthuyzen et al.

Park (TWP) Pieh Island, West Sumatra.

Proceedings of IOP Conf. Ser.: Earth and Environ. Sci. 284, (012028), 1-9.

https://doi.org:10.1088/1755-1315/284/1/ 012028

Zhang, Z., Falter, J., Lowe, R., Ivey, G., \& McCulloch, M. (2013). Atmospheric forcing intensifies the effects of regional ocean warming on reef-scale temperature anomalies during a coral bleaching event. Journal of Geophysical Research: Oceans, 118(9), 4600-4616.

https://doi.org/10.1002 /jgrc.20338 